Estuarine, Coastal and Shelf Science

September 2016, Volume 179, Pages 155-171

http://dx.doi.org/10.1016/j.ecss.2015.11.018

http://archimer.ifremer.fr/doc/00299/40984/

(c) 2015 Elsevier Ltd. All rights reserved.

\title{
Poleward along-shore current pulses on the inner shelf of the Bay of Biscay
}

\author{
Kersalé M. ${ }^{1,{ }^{*}}$, Marié Louis ${ }^{2}$, Le Cann B. ${ }^{1}$, Serpette A. ${ }^{3}$, Lathuilière C. ${ }^{3}$, Le Boyer A. ${ }^{3}$, Rubio A. ${ }^{4}$, \\ Lazure Pascal ${ }^{5}$
}

${ }^{1}$ Laboratoire de Physique des Océans, UMR 6523 CNRS-Ifremer-IRD-UBO, Université de Bretagne Occidentale, Brest, France

${ }^{2}$ Laboratoire de Physique des Océans, UMR 6523 CNRS-Ifremer-IRD-UBO, Ifremer, Centre de

Bretagne, Plouzané, France

${ }^{3}$ Division HOM, Service Hydrographique et Océanographique de la Marine, Brest, France

${ }^{4}$ AZTI-Marine Research, Herrera Kaia, Portualdea z/g, 20110, Pasaia, Spain

${ }^{5}$ Ifremer, Dyneco, BP70, Plouzané, France

* Corresponding author : Marion Kersalé, email address : marion.kersale@univ-brest.fr

\begin{abstract}
:
We analyzed strong events of coastal poleward along-shore currents above $10 \mathrm{~cm} \mathrm{~s}-1$ and up to more than $50 \mathrm{~cm} \mathrm{~s}-1$ on the inner shelf (50-80 m depth) of the Bay of Biscay (BoB) from the Spanish coast to the Brittany coast. We used data from four acoustic Doppler current profilers (ADCPs) deployed from July 2009 to August 2011. The goal of this study was to analyze current variability at meso- and subinertial scales and their generation mechanisms. These currents occurred all year long and were classified into three types. Events occurring principally in the southern part of the BoB were classified as southern events. Bay-scale events were defined when strong poleward currents were detected over all the shelf, typically stronger on the Spanish and the southern Brittany shelves. Strong events were characterized by depth averaged current velocities over $40 \mathrm{~cm} \mathrm{~s}-1$ in the southern part of the BoB. At short time lags, the along-shore currents were clearly related to along-shore wind stress at upstream locations. An explanation is provided for longer time lags in terms of coastal trapped wave (CTW) dynamics. The first CTW mode phase speeds were in agreement with the propagation speeds of the fastest events (> $5 \mathrm{~m} \mathrm{~s}-1$ ), while inner shelf modes could explain the slowest events ( 1-3 m s-1). The cross-shelf density gradient and the extension of the IPC were also associated with strong coastal poleward along-shore currents. The duration of the events, the vertical structure of the currents and the associated coastal trapped waves were studied in relation with the stratification.
\end{abstract}

Keywords : Coastal Jets, ADCP, Shelf circulation, Wind forcing, Coastal Trapped Waves, Bay of Biscay 


\section{Introduction}

Eastern boundary current systems are characterized by the generation of strong and intermittent poleward currents [7]. In many cases, these poleward flows are surface intensified and encompass the shelf. Several mechanisms have been suggested for their generation. A number of local forcings can be identified such as buoyancy, wind and rectification of coastal trapped waves (CTWs). Considering the frequent occurrence of such poleward currents flowing against prevailing equatorward winds, largerscale, non-local forcing mechanisms, that may be mediated by CTWs, have been proposed and classified by [27]. These authors show that an along-shore surface slope or an offshore pressure gradient can also generate these flows. The establishment of these pressure gradients can be due to regional wind stress and meridional density gradients, known as the joint effect of baroclinicity and relief [JEBAR, 29], and can be modified by along-slope topography.

Studies of those dynamical processes which govern continental shelves have been reported along the U.S. west coast [e.g. recently in $34,70,47,50$ ] and along the Mexican west coast [17]. The continental shelf north of San Francisco [Coastal Ocean Dynamics Experiment - CODE, 4], the Western Florida shelf [45] and the central west coast of India [2] have been also proposed as typical regions of poleward flows. The most recent studies, described above, were based on experimental results from highfrequency (HF) radar systems or multi-year 
Acoustic Doppler current profilers (ADCPs) measurements. The Australian Coastal Experiment [ACE, 20], conducted in the coastal waters of New South Wales (east coast of Australia) with a three main lines array of current meters, was the most ambitious early observational study aimed specifically at coastally trapped waves. The data obtained allowed a detailed examination of the dynamics of flow on the continental shelf and slope and in particular a description of coastal trapped wave modes propagating within the coastal waveguide.

Despite its complex topography, the Bay of Biscay (BoB - Figure 1), located at mid-latitudes in the north-eastern Atlantic, off western Europe, exhibits the classical current system found in eastern boundary regions, with poleward flow on the shelf and slope [53, 35, 37]. The BoB, area of interest in this study, is characterized by three main parts (Figure 1): an abyssal plain, a continental slope and a northward widening continental shelf $\left(\sim 20 \mathrm{~km}\right.$ at $3^{\circ} \mathrm{W}$ - Spanish

35 shelf, $\sim 60 \mathrm{~km}$ at $44^{\circ} \mathrm{N}$ - Aquitaine shelf, $\sim 150 \mathrm{~km}$ at $47^{\circ} \mathrm{N}$ - Armorican shelf). The North Atlantic circulation over the abyssal plain has been relatively well studied in several works [53, 52, 66, 14, 12]. The averaged, anticyclonic, circulation is characterized by weak values $\left(1-2 \mathrm{~cm} \mathrm{~s}^{-1}\right)$ but larger velocities due to mesoscale dynamics [51] are observed, such as anticyclonic eddies [54].

40 Along the slope, the currents are characterized by a cyclonic circulation with higher mean velocities, $5-10 \mathrm{~cm} \mathrm{~s}^{-1}[55]$. These currents exhibit a strong seasonality. The along-slope circulation is marked by the occurrence of an intensified poleward surface flow (Iberian Poleward Current - IPC) in autumn and winter north of the Iberian Peninsula. Stronger over the upper part of the slope, the 45 signature of the IPC, a warm and saline current, has been described in different studies [21, 54, 57, 63]. This eastward current can reach velocities over $70 \mathrm{~cm} \mathrm{~s}^{-1}$ and can extend to the Aquitaine and Armorican upper slopes [43, 22]. The general features of the circulation on the shelf have been described. [12] suggest a link between the northern Spanish shelf circulation and the one of the Aquitaine shelf similar to the continuity of the slope current from Spanish to Celtic slopes [55]. Several studies have been undertaken to describe the main ocean processes affecting the Spanish shelf and slope circulation [25, 65, 19, 59, 
1]. A detailed description of the dominant surface current patterns observed by HF radars in the southeast corner of the BoB has been proposed by [63, 62] in relation to seasonal, mesoscale and high-frequency variability. Over the French shelves, weak values with residual sub-tidal currents of about $3 \mathrm{~cm} \mathrm{~s}^{-1}$ have been measured [53, 41]. [12] have shown a strong seasonality of the surface current direction: equatorward in spring and summer, and poleward in winter and autumn. These changes are driven by the seasonal variation of wind [53, 55]. At smaller spatial scales, the freshwater discharges induce also a significant circulation over the inner shelf, especially in the Gironde and Loire plumes [39, 40, 16]. On the northern Armorican shelf, a cold pool of water $\left(12^{\circ} \mathrm{C}\right)$ centered between $60 \mathrm{~m}$ and $120 \mathrm{~m}$ depths is present from spring to autumn. This pool of dense water, called "bourrelet froid" [for "cold pool", 68], is associated with surface 65 cyclonic circulation [12].

Influenced by large-scale oceanic basin circulation and by local forcings, such as seasonal wind regimes and important river discharges, the BoB shelf circulation is frequently affected by the occurrence of poleward flows. These poleward flows appear as intermittent and locally variable currents, defined as pulses, and have been reported during different seasons in the BoB. On a weekly scale, the shelf is associated with strong surface currents near the coast in the northern part of the domain in winter and strong currents affecting the whole water column in the southern part of the domain in autumn [41]. Indeed, poleward flows on the shelf exist all year long, with stronger intensity in autumn-winter than in spring-summer [12]. From October to March, marked weekly poleward currents (up to $15 \mathrm{~cm} \mathrm{~s}^{-1}$ ) are observed over the Aquitaine shelf.

A summer poleward coastal event of up to $32 \mathrm{~cm} \mathrm{~s}^{-1}$ during 22 days along the Aquitaine shelf was investigated using ADCP and drifting buoys measurements by [3]. One possible mechanism of this event was reported and linked to westerlies, along-shore wind events inducing downwelling conditions along the Spanish coast. This downwelling induces an along-shore pressure gradient and can generate CTW and Kelvin waves [3]. 38] described an autumn poleward 
current over the Armorican shelf up to $20 \mathrm{~cm} \mathrm{~s}^{-1}$. The mechanism of this event was linked by the authors to the breakdown of stratification at this season, inducing strong cross-shore density gradients. In both cases (summer and autumn events), a bottom front is generated and, following the thermal wind balance, a surface intensified poleward density driven current is generated.

Due to intense fishing activity, long-term moorings have rarely been deployed over the shelf, even if an understanding of the shelf dynamics and its seasonality is crucial for many studies, e.g. on vertical distribution of phytoplankton [15], dispersion of harmful algal blooms [56] or seabed morphodynamics [46]. To improve our knowledge of the shelf circulation of the BoB, the objective of the ASPEX project was to observe the shelf and upper continental slope circulation

\section{Data and Methods}

This study was conducted within the framework of the ASPEX project, an experimental component of the EPIGRAM project (Études Physiques Intégrées en Gascogne et Région Atlantique-Manche). The ASPEX project was based on the deployment of twelve moorings, for two consecutive years, from July 2009 to August 2011 (hereafter named ASPEX period) on the BoB $60 \mathrm{~m}, 130 \mathrm{~m}$ and $450 \mathrm{~m}$ isobaths, along three cross-shelf sections [41]. Since our main focus was 
on the shelf dynamics, we used only the three current-meter moorings deployed over the inner shelf: $A S P E X 1$ from the Penmarc'h section (hereafter named (1)

(hereafter named M2), north of the Capbreton Canyon, at $44^{\circ} \mathrm{N}$ (Figure1). All the moorings were bottom mounted and equipped with RDI WorkHorse ADCPs operating at $300 \mathrm{kHz}$ and a SBE37 Microcat T/S/P recorder. Moorings were deployed twice (July 2009 and August 2010) for approximately one year period each 41, , table 1. The ADCP were gimbal-mounted on frames at $71 \mathrm{~m}$ depth for $M 4,47-52 \mathrm{~m}$ depth for $M 3$ and $54 \mathrm{~m}$ depth for $M 2$. The sampling period was $30 \mathrm{~s}$. The readers are referred to [41] for more details about the characteristics of the recorded data and data processing. The collected data were averaged over 20 min periods and tidally filtered. We used the "120i913" filter designed

125 by [64]. This filter has a 1.4 days cut-off period and a steep response curve. In the following we define the along-shore direction as the one of the major axis of the depth-averaged and filtered currents variance ellipse [48]. The tidally filtered currents were projected onto these along-shore and cross-shore directions. These are defined positive poleward and positive onshore.

In order to achieve a wider coverage of the area, we also used data from a downward-looking WorkHorse ADCP operating at $300 \mathrm{kHz}$ located at $7.5 \mathrm{~m}$ depth on a buoy operated by AZTI on an open sea test infrastructure with $79 \mathrm{~m}$ water depth (Biscay Marine Energy Platform-BIMEP). This ADCP (hereafter named $M 1$, Figure 1) covered the ASPEX period with a sampling period of 1 hour. The same processing of the data (tide filtering and projection) was applied. For the raw $M 1$ data, beam amplitude, beam correlation magnitudes and vertical velocity errors were used for the data processing and quality tests, following $[6]$. Then, standard procedures were applied to perform a quality control 67]. Additional inaccuracies could be expected due to the horizontal drift of the surface buoy where the ADCP was mounted. Using data from a GPS fixed on similar moorings existing over the upper slope in the study area, [59] estimated these to be under $4 \mathrm{~cm} \mathrm{~s}^{-1}$.

The characteristics of the ADCP data used in this study are summarized in 


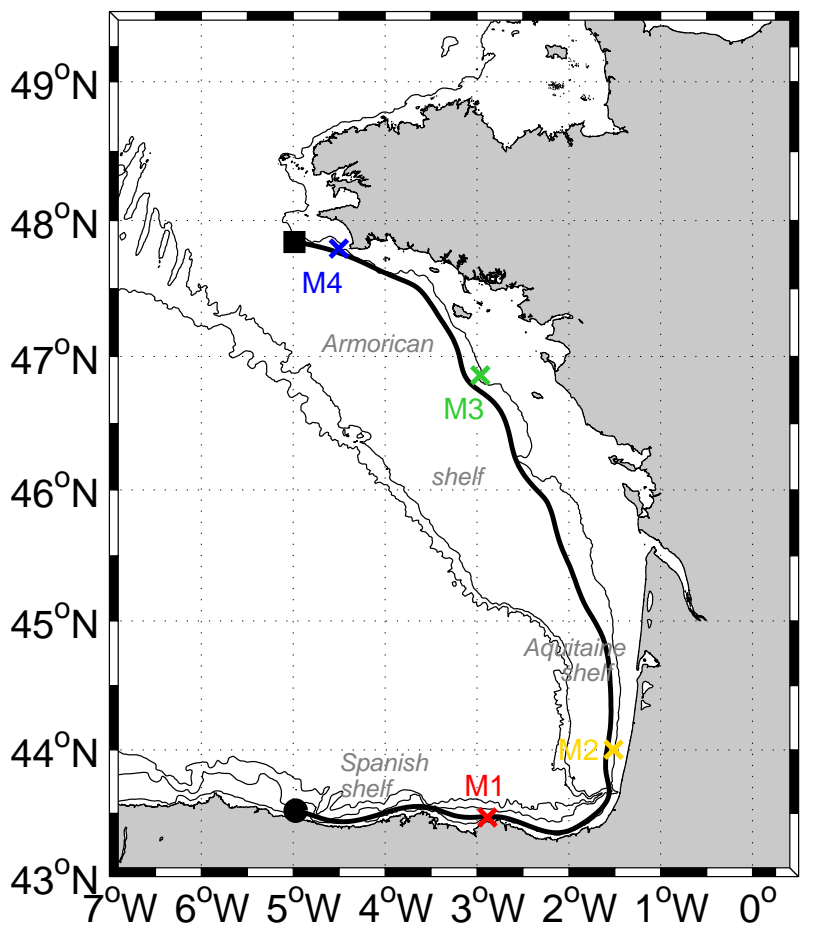

Figure 1: Study area and moorings position. The thick black line denotes the positions along the $100 \mathrm{~m}$ isobath section where the component of the wind stress is calculated and projected. The black dot (black square) represent the beginning (end) of the $100 \mathrm{~m}$ isobath section used for wind stress plots. Thin black lines indicate the 60, 130 and 450 isobaths.

Table 1.

The set of records presented hereafter were all low-passed currents (i.e. filtering out inertial and tides up to diurnal species using the Thompson filter mentioned above). Description of the different along-shore current events will be given, with a classification into three main types. All the events were characterized at $M 1$ by depth averaged poleward current velocities larger than $14 \mathrm{~cm} \mathrm{~s}^{-1}$ and standard deviations greater than $8 \mathrm{~cm} \mathrm{~s}^{-1}$ within the period of the events. Events occurring principally at $M 1$ and $M 2$ will be classified as "southern events". These events will be characterized by depth averaged poleward current velocities larger than $10 \mathrm{~cm} \mathrm{~s}^{-1}$ at $M 1$ and $M 2$. These events corresponded approximately to the $10 \%$ of the total time series. We will refer to "bay-scale events" when along-shore current event extends toward the north 
Table 1: Moorings characteristics.

\begin{tabular}{cccccc}
\hline & ASPEX 1 & ASPEX 4 & ASPEX 7 & BIMEP \\
& $M 4$ & $M 3$ & $M 2$ & $M 1$ \\
\hline & Latitude (N) & $47^{\circ} 48^{\prime}$ & $46^{\circ} 52^{\prime}$ & $44^{\circ}$ & $43^{\circ} 28^{\prime}$ \\
& Longitude (W) & $-4^{\circ} 30^{\prime}$ & $-2^{\circ} 58^{\prime}$ & $-1^{\circ} 31^{\prime}$ & $-2^{\circ} 53^{\prime}$ \\
& Cell Size (m) & 2 & 2 & 2 & 10 \\
& Sampling period (s) & 30 & 30 & 30 & 3600 \\
\hline \multirow{2}{*}{$2009-2010$} & Water depth (m) & 71 & 52 & 54 & 79 \\
& Start & $2009 / 07 / 13$ & $2009 / 07 / 15$ & $2009 / 07 / 19$ & $2009 / 07 / 13$ \\
& End & $2010 / 05 / 13$ & $2010 / 06 / 29$ & $2010 / 06 / 29$ & $2010 / 07 / 01$ \\
\hline \multirow{2}{*}{$010-2011$} & Water depth (m) & 71 & 47 & 54 & 79 \\
& Start & $2010 / 08 / 31$ & $2010 / 09 / 02$ & $2010 / 09 / 05$ & $2010 / 08 / 31$ \\
& End & $2011 / 08 / 07$ & $2011 / 08 / 09$ & $2011 / 08 / 10$ & $2011 / 08 / 13$ \\
\hline
\end{tabular}

and when poleward currents are larger than $10 \mathrm{~cm} \mathrm{~s}^{-1}$ both in the southern and northern parts of the BoB (approximately $10 \%$ of the total time series). We used $M 1$ and $M 4$ for evaluating this type of events. When no data was available at $M 1$ during this type of events, we used instead data from $M 2$. Finally, "strong events" will be characterized by poleward current velocities larger than $40 \mathrm{~cm} \mathrm{~s}^{-1}$ at $M 1$ and $M 2$ (corresponding approximately to $1 \%$ of the total time series). The start (end) time of all three types of events was set up when the poleward current velocities increase over (decrease under) $10 \mathrm{~cm} \mathrm{~s}^{-1}$.

To understand the dynamics of the $\mathrm{BoB}$ circulation, we compared the current velocities and the wind data over the two years of measurements. This comparison was investigated using wind data from the 1 hour outputs of AROME atmospheric circulation model [61], with a spatial resolution of $2.5 \mathrm{~km}$. During January 2010, wind data was not available in the AROME model. We used instead the data from the 3 hours outputs of ALADIN model [28], with a spatial resolution of $7.5 \mathrm{~km}$. AROME and ALADIN are both meteorological analysis and forecast models from Météo-France over the Western Europe. Wind speeds were used to estimate wind stress values using a quadratic formula that relates the wind speed at $10 \mathrm{~m}$ above the sea surface to a stress value through the use of a neutral drag coefficient [36]. The model outputs were extracted every 
$6 \mathrm{~h}$ along the $100 \mathrm{~m}$ isobath every $10 \mathrm{~km}$, starting from $5^{\circ} \mathrm{W}$ (Figure 11). The projection of the wind speed components and the calculation of the along-shore and cross-shore wind stress were made along this line. Wind stress components are defined as positive poleward and positive onshore.

In addition, satellite sea surface imagery was analyzed to give an overview of the dynamics in the area. Sea Surface Temperature (SST) was derived from the Moderate-resolution Imaging Spectroradiometer (MODIS) radiometer on board the NASA Terra and Aqua satellite platforms (http://oceandata.sci.gsfc.nasa.gov/MODISA/). Weekly (8 day) MODIS SST composite products were used at $4.63 \mathrm{~km}$ spatial resolution. To characterize the stratification of the water column, hourly SST time series, at the nearest point of each mooring, from the geostationary Spinning Enhanced Visible and Infrared Imager (SEVIRI, http://www.osi-saf.org/) were compared to the bottom temperature records from the SBE recorder. This comparison gave us the opportunity to detect thermal inversions, sustained by haline stratification, with colder waters in the surface layer. Particular attention is paid to the presence of stratification (thermal or haline) because it influences the vertical structure of the poleward current events and the generation of CTWs.

\section{The events}

Eighteen events of poleward currents were identified from 15 July 2009 to 30 June 2010 (Table 2) and twenty events from 1 September 2010 to 7 August 2011 (Table 3). The specific characteristics of the different events (hereafter named as \#EN, being $\mathrm{N}$ a number assigned in chronological order) for these two periods are described in detail in Appendix A1.1 and Appendix A1.2 respectively.

\subsection{Southern events}

During thirteen southern events, with a typical duration of 2-9 days, alongshore currents were most intense on the north Spanish shelf (M1), up to $43.5 \mathrm{~cm} \mathrm{~s}^{-1}$ 
Table 2: Summary for the 2009/2010 period - Pulses characteristics: Type and name of the events, maximum of depth-averaged poleward along-shore currents $\left[\mathrm{cm} \mathrm{s}^{-1}\right]$ at each mooring, dates, duration (in days, d) and number of pulses.

\begin{tabular}{ccccccccc}
\hline Type & Name & M1 & M2 & M3 & M4 & Dates & Duration & Pulses \\
\hline \multirow{6}{*}{ Bay-scale } & \#E1 & 25.7 & 16.0 & 3.4 & 13.7 & $23-30 / 07 / 09$ & $7.3 \mathrm{~d}$ & 2 \\
& \#E2 & 18.2 & 15.1 & 4.0 & 14.6 & $02-06 / 08 / 09$ & $4.5 \mathrm{~d}$ & 1 \\
& \#E5 & 15.2 & 5.2 & 7.3 & 13.5 & $21-24 / 10 / 09$ & $2.1 \mathrm{~d}$ & 1 \\
& \#E7 & 21.5 & 8.6 & 12.4 & 20.8 & $11-17 / 11 / 09$ & $5.4 \mathrm{~d}$ & 2 \\
& \#E11 & No data & 11.8 & 13.2 & 14.9 & $21-24 / 12 / 09$ & $3.3 \mathrm{~d}$ & 1 \\
& \#E12 & No data & 16.2 & 11.6 & 18.5 & $28 / 12-05 / 01 / 10$ & $8.4 \mathrm{~d}$ & 4 \\
& \#E13 & 31.8 & No data & 4.6 & 12.4 & $05-11 / 02 / 10$ & $6.0 \mathrm{~d}$ & 2 \\
& \#E14 & 29.3 & 16.7 & 19.6 & 22.0 & $17 / 02-04 / 03 / 10$ & $14.8 \mathrm{~d}$ & 4 \\
& \#E15 & 35.4 & 7.7 & 9.3 & 14.6 & $19-29 / 03 / 10$ & $10.1 \mathrm{~d}$ & 4 \\
\hline \multirow{5}{*}{ Southern } & \#E3 & 29.2 & 10.0 & -8.0 & -7.0 & $03-07 / 09 / 09$ & $4.3 \mathrm{~d}$ & 1 \\
& \#E4 & 27.9 & 16.8 & -9.7 & -2.6 & $19-24 / 09 / 09$ & $4.8 \mathrm{~d}$ & 1 \\
& \#E8 & 29.9 & 14.7 & 1.5 & -14.8 & $21-24 / 11 / 09$ & $2.2 \mathrm{~d}$ & 1 \\
& \#E10 & 20.7 & 10.9 & -3.3 & 6.1 & $07-09 / 12 / 09$ & $2.3 \mathrm{~d}$ & 1
\end{tabular}

and on the Aquitaine shelf (M2), up to $26.4 \mathrm{~cm} \mathrm{~s}^{-1}$ (Tables 2, 3). The temporal evolution of the currents at $M 1$ and $M 2$ followed the same tendency, with poleward along-shore currents larger than $10 \mathrm{~cm} \mathrm{~s}^{-1}$. During these events, equatorward or weak poleward pulses were recorded at $M 3$ and $M 4$. We selected \#E4 and \#E17 as the most representative events of this type.

During \#E4, occurring between 19 September and 24 September 2009, the intensity of the along-shore currents reached $27.9 \mathrm{~cm} \mathrm{~s}^{-1}$ on the Spanish shelf and $16.8 \mathrm{~cm} \mathrm{~s}^{-1}$ on the Aquitaine shelf (Figure 2-a). Along-shore currents at $M 3$ and $M 4$ were oriented equatorward during this event. This event, and more generally during the periods from July to October 2009 and from September to October 2010, was characterized by currents typically more intense in the first $30 \mathrm{~m}$ of the water column (Figure2-d). This depth corresponded to the depth of 
Table 3: Summary for the 2010/2011 period - Pulses characteristics: Type and name of the events, maximum of depth-averaged poleward along-shore currents $\left[\mathrm{cm} \mathrm{s}^{-1}\right]$ at each mooring, dates, duration (in days, d) and number of pulses.

\begin{tabular}{ccccccccc}
\hline Type & Name & M1 & M2 & M3 & M4 & Dates & Duration & Pulses \\
\hline \multirow{5}{*}{ Bay-scale } & \#E23 & 45.8 & 15.6 & 13.8 & 24.3 & $28 / 10-04 / 11 / 10$ & $6.8 \mathrm{~d}$ & 2 \\
& \#E25 & 37.6 & 21.2 & 18.9 & 19.2 & $13-21 / 11 / 10$ & $7.9 \mathrm{~d}$ & 3 \\
& \#E26 & No data & 20.7 & 15.5 & 19.2 & $05-09 / 12 / 10$ & $3.7 \mathrm{~d}$ & 2 \\
& \#E29 & 27.0 & 6.8 & 12.3 & 16.6 & $27-31 / 01 / 11$ & $4.1 \mathrm{~d}$ & 2 \\
& \#E30 & 54.5 & 17.8 & 15.1 & 28.6 & $08-20 / 02 / 11$ & $11.5 \mathrm{~d}$ & 5 \\
& \#E31 & 34.1 & 9.3 & 0.1 & 12.4 & $15-19 / 03 / 11$ & $4.1 \mathrm{~d}$ & 1 \\
& \#E32 & 21.9 & 10.0 & 7.0 & 11.9 & $27 / 03-04 / 04 / 11$ & $7.8 \mathrm{~d}$ & 3 \\
& \#E33 & 20.2 & 8 & 2.1 & 13.6 & $20-28 / 04 / 11$ & $8.5 \mathrm{~d}$ & 2 \\
& \#E34 & 24.4 & 9.1 & 6.4 & 11.5 & $06-13 / 05 / 11$ & $6.5 \mathrm{~d}$ & 2 \\
\hline \multirow{5}{*}{ southern } & \#E19 & 33.8 & 12.3 & 4.3 & 6.4 & $04-13 / 09 / 10$ & $8.9 \mathrm{~d}$ & 2 \\
& \#E20 & 28.7 & 16.0 & 1.3 & 2.2 & $22-28 / 09 / 10$ & $5.1 \mathrm{~d}$ & 2 \\
& \#E22 & 21.4 & 15.2 & -0.4 & -2.0 & $24-26 / 10 / 10$ & $2.1 \mathrm{~d}$ & 1 \\
& \#E27 & 30.1 & 10.0 & 5.0 & 5.9 & $11-19 / 01 / 11$ & $8.4 \mathrm{~d}$ & 4 \\
& \#E35 & 28.4 & 15.1 & 2.2 & 2.8 & $13-21 / 06 / 11$ & $8.7 \mathrm{~d}$ & 2 \\
& \#E36 & 15.1 & 12.8 & 0.8 & 1.0 & $13-15 / 07 / 11$ & $1.9 \mathrm{~d}$ & 1 \\
& \#E38 & 16.2 & 26.4 & 7.0 & 8.8 & $25-30 / 07 / 11$ & $4.1 \mathrm{~d}$ & 2 \\
\hline \multirow{5}{*}{ Strong } & \#E21 & 65.7 & 45.5 & 21.2 & 27.9 & $02-17 / 10 / 10$ & $14.8 \mathrm{~d}$ & 4 \\
& \#E24 & 61.3 & 42.9 & 12.6 & 13.9 & $07-11 / 11 / 10$ & $3.5 \mathrm{~d}$ & 1 \\
& \#E37 & 48.0 & 44.9 & 4.2 & 3.5 & $17-23 / 07 / 11$ & $7.1 \mathrm{~d}$ & 3 \\
\hline
\end{tabular}

the seasonal thermocline, which was estimated with ScanFish sections in midJuly 2009 (data not shown). The mean temperature evidenced the presence of a thermal stratification with surface temperature around $15-20^{\circ} \mathrm{C}$ and bottom temperature between $12-13^{\circ} \mathrm{C}$ (Figure 2-b). During \#E4, along-shore currents were associated with an increase of bottom temperature of $1^{\circ} \mathrm{C}$ at $M 2$ (Figure 2 b). This event was associated with strong values of along-shore components of the wind stress (up to $0.2 \mathrm{~Pa}$, Figure 2-c). Positive values were recorded along the Spanish coast (first $300 \mathrm{~km}$ along the $100 \mathrm{~m}$ isobath, Figure 1) and negative values along the French coast.

\#E17, occurring mid-May 2009 (11-20 May 2010), was classified as a south${ }_{225}$ ern event, as it appeared mainly at $M 1$ and $M 2$. The intensity of the depth- 

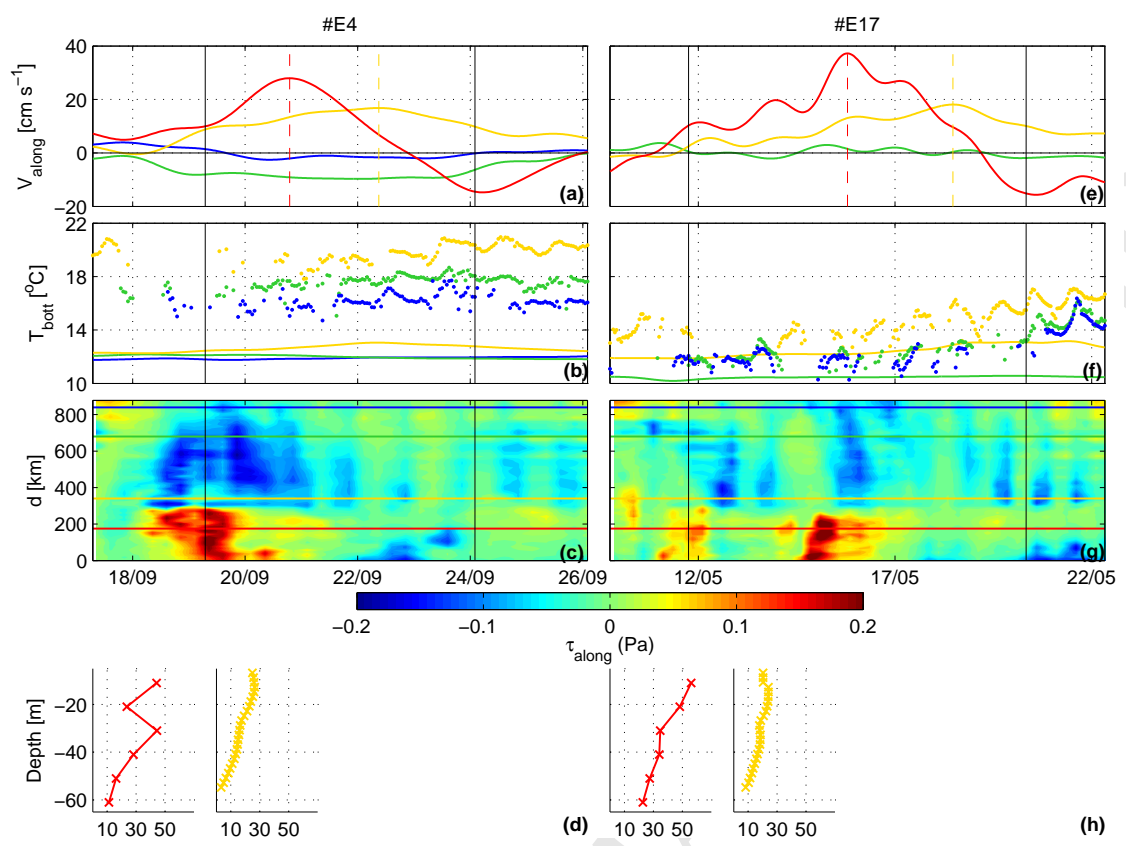

(h)

Figure 2: Southern events. \#E4: left column; \#E17: right column. (a,e) Temporal evolution of the depth-averaged along-shore component of the current velocity [ $\mathrm{cm} \mathrm{s}^{-1}$ ] at M1 (red line), M2 (yellow line), M3 (green line) and M4 (blue line). For all the figures, the color code is the same and the vertical black solid lines represent the beginning and the end of the poleward event recorded. (b,f) The solid lines represent the temporal evolution of the bottom temperature $\left[{ }^{\circ} \mathrm{C}\right]$. Dots represent the surface temperature $\left[{ }^{\circ} \mathrm{C}\right]$ from SEVIRI images. $(\mathrm{c}, \mathrm{g})$ Temporal evolution with distance $[\mathrm{km}]$ along the $100 \mathrm{~m}$ isobath (cf Figure 1) of the along-shore component of the wind stress $[\mathrm{Pa}]$ from the AROME model. The horizontal lines represent the along-shore distances where the moorings are positioned. $(\mathrm{d}, \mathrm{h})$ Vertical profile of the along-shore component of the current velocity $\left[\mathrm{cm} \mathrm{s}^{-1}\right]$ for the maximum of the poleward event recorded at $M 1$ and $M 2$ (vertical dotted lines-a,e).

averaged along-shore current was stronger on the Spanish shelf, up to $37.3 \mathrm{~cm} \mathrm{~s}^{-1}$, than on the Aquitaine shelf, up to $18.1 \mathrm{~cm} \mathrm{~s}^{-1}$ (Figure 2-e). Weak intensity poleward pulses were recorded at $M 3$ and no data was available at $M 4$ during this event. The water column was relatively well mixed until \#E17 (Figure2-f), when the establishment of a thermal stratification was observed in mid-May (increase of surface temperature from 14 to $17^{\circ} \mathrm{C}$ ). The mean bottom temperature 
increased slowly from $12^{\circ} \mathrm{C}$ to $13^{\circ} \mathrm{C}$ at $M 2$. The core of the events encompassed the first $30 \mathrm{~m}$ of the water column at $M 1$ and $M 2$ (Figures 2-h). The along-shore wind stress along the coast was similar to that of \#E4, with positive values recorded along the Spanish coast and negative values along the French coast (Figure 2-g). Similarly, \#E33 occurring mid-April 2010 was simultaneous with the establishment of a thermal stratification.

\subsection{Bay-scale events}

Twenty events were classified as bay-scale events as poleward along-shore currents at $M 1$ and $M 4$ are larger than $10 \mathrm{~cm} \mathrm{~s}^{-1}$ (Tables 2, 3). These events had a typical duration between 2-15 days, with intense along-shore currents on the north Spanish shelf, between $15.2-54.5 \mathrm{~cm} \mathrm{~s}^{-1}$. On the French coast, these events were marked at $M 4$ with a maximum depth-averaged along-shore component between $11.5-28.6 \mathrm{~cm} \mathrm{~s}^{-1}$. The currents at $M 2$ and $M 3$, followed generally the same temporal evolution as the current at $M 4$ with weaker alongshore currents $\left(0-21.1 \mathrm{~cm} \mathrm{~s}^{-1}\right)$. We selected \#E34 as the most representative event of this type. \#E30 was also studied as its characteristics were different from the other bay-scale events.

\#E34 (6-13 May 2010), a characteristic bay-scale event, occurred during the establishment of the spring thermal stratification. During this event, along-shore currents were intense on the north Spanish shelf $\left(24.4 \mathrm{~cm} \mathrm{~s}^{-1}\right.$, Figure $3 \mathrm{r}$ a). On the French coast, this event was marked at $M 4$ with a maximum depth-averaged along-shore component of $11.5 \mathrm{~cm} \mathrm{~s}^{-1}$. The signal exhibited three consecutive pulses. The currents at $M 2$ and $M 3$, had generally the same temporal evolution with weaker along-shore currents $\left(6.4-9.1 \mathrm{~cm} \mathrm{~s}^{-1}\right)$. The mean surface temperature was equal to $15^{\circ} \mathrm{C}$ and the bottom temperature at values between $11-13^{\circ} \mathrm{C}$ (Figure 3-b). With this thermal stratification, the core of the events encompassed the first $30 \mathrm{~m}-40 \mathrm{~m}$ of the water column (Figure 3-d). The wind was highly variable in the bay during this period (Figure $3 \mathrm{r}$ c). The pulses were associated with a succession of short bursts of wind with positive along-shore wind stress values along the French coast and negative values along the Spanish 
one.

\#E30, with a duration of 2.5 days (21-24 February 2011) was characterized by strong poleward along-shore currents at $M 1\left(54.5 \mathrm{~cm} \mathrm{~s}^{-1}\right.$, Figure $\left.3 \mathrm{re}\right)$. The temporal evolution of the depth-averaged along-shore component of the current velocity at the four moorings followed the same tendency, even if lower velocities were recorded at $M 2\left(17.8 \mathrm{~cm} \mathrm{~s}^{-1}\right), M 3\left(6 \mathrm{~cm} \mathrm{~s}^{-1}\right)$ and $M 4\left(13.5 \mathrm{~cm} \mathrm{~s}^{-1}\right)$. This event was generated during a period of intense IPC episode mentioned by [63]. During this event, the water column was relatively well mixed and the currents relatively uniform vertically for $M 1, M 2$ and $M 3$ (Figures $3 \mathrm{f}$-f,h). During winter, it is common to observe a vertical thermal inversion in the northern part of the BoB (Figure 3 f f). During this haline stratification, the event was reduced to the top $30 \mathrm{~m}$ of the water column at M4 (Figure 3-h). Strong wind stress was observed during this event, with positive wind stress over the Spanish shelf and negative values over the French shelf (Figure $3 \mathrm{rg}$ ).
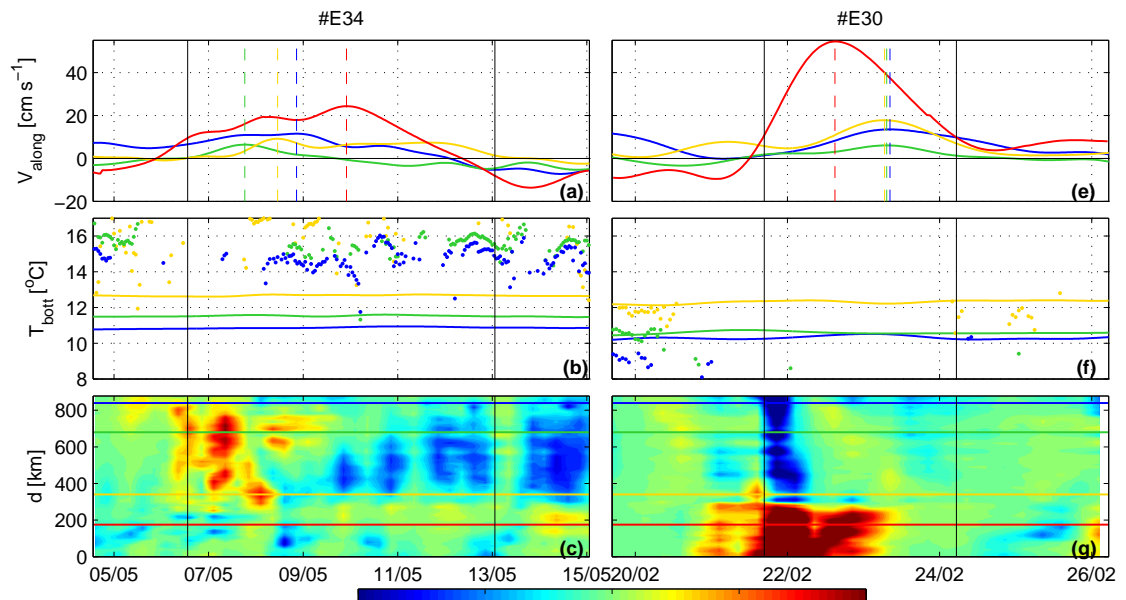


\subsection{Strong events}

Finally, we distinguished five strong events, with along-shore poleward currents at $M 1$ and $M 2$ larger than $40 \mathrm{~cm} \mathrm{~s}^{-1}$ (Tables 2. 3). Three events in autumn (\#E6, \#E21 and \#E24) and two events in summer (\#E18 and \#E37) exhibited an intense poleward current at $M 1$ and $M 2$ with an overall maximum depth-averaged along-shore velocity of 65.7 and $55.3 \mathrm{~cm} \mathrm{~s}^{-1}$ respectively, and durations between 3-15 days. The currents at $M 3$ and $M 4$ were also poleward but much weaker $\left(0-27.9 \mathrm{~cm} \mathrm{~s}^{-1}\right)$. We selected events \#E6 for autumn season and \#E18 for summer season as the most representative events of this type.

\#E6 was identified during November 2009 (31 October - 10 November 2009), when a strong poleward current started increasing, until reaching a maximum depth-averaged along-shore velocity of $54.9 \mathrm{~cm} \mathrm{~s}^{-1}$ at $M 1$ and $55.3 \mathrm{~cm} \mathrm{~s}^{-1}$ at M2 (Figure 4-a). It was generated during a period of intense IPC [63]. This event was not apparent at $M 3$ and $M 4$, characterized by weak poleward or equatorward currents. During \#E6, an increase of along-shore current velocity, over the first $60 \mathrm{~m}$ of the water column along with a slight decrease of the intensity near the bottom (Figure 44d), were associated with an increase of bottom temperature of $2-3^{\circ} \mathrm{C}$ at $M 2$, which marked the end of the vertical stratification (Figure 4 $\mathrm{b}$ ). An intense and extended wind blowing during 7 days was observed during this event (Figure 4c). Strong along-shore positive wind stress values were identified along the Spanish coast and strong negative values along the French coast. Similarly, for the 2010-2011 period, \#E24 with the same properties marked the end of the vertical stratification.

The second selected strong event (\#E18) was observed at M1, M2 and M3 between 10 June and 22 June 2010 (Figure 4-e). On 9 June, a strong poleward current started increasing, until reaching a maximum depth-averaged alongshore velocity of $50.2 \mathrm{~cm} \mathrm{~s}^{-1}$ at $M 1$ and $16.9 \mathrm{~cm} \mathrm{~s}^{-1}$ at $M 3$ on 12 June. More than five days later (on 18 June), an intense poleward current was recorded at $M 2\left(47.3 \mathrm{~cm} \mathrm{~s}^{-1}\right)$. No data was available at $M 4$. The core of the event encompassed the first $50 \mathrm{~m}$ of the water column (Figure 4-h). Associated with the sharply rising along-shore current velocity of \#E18, a marked increase in bottom 

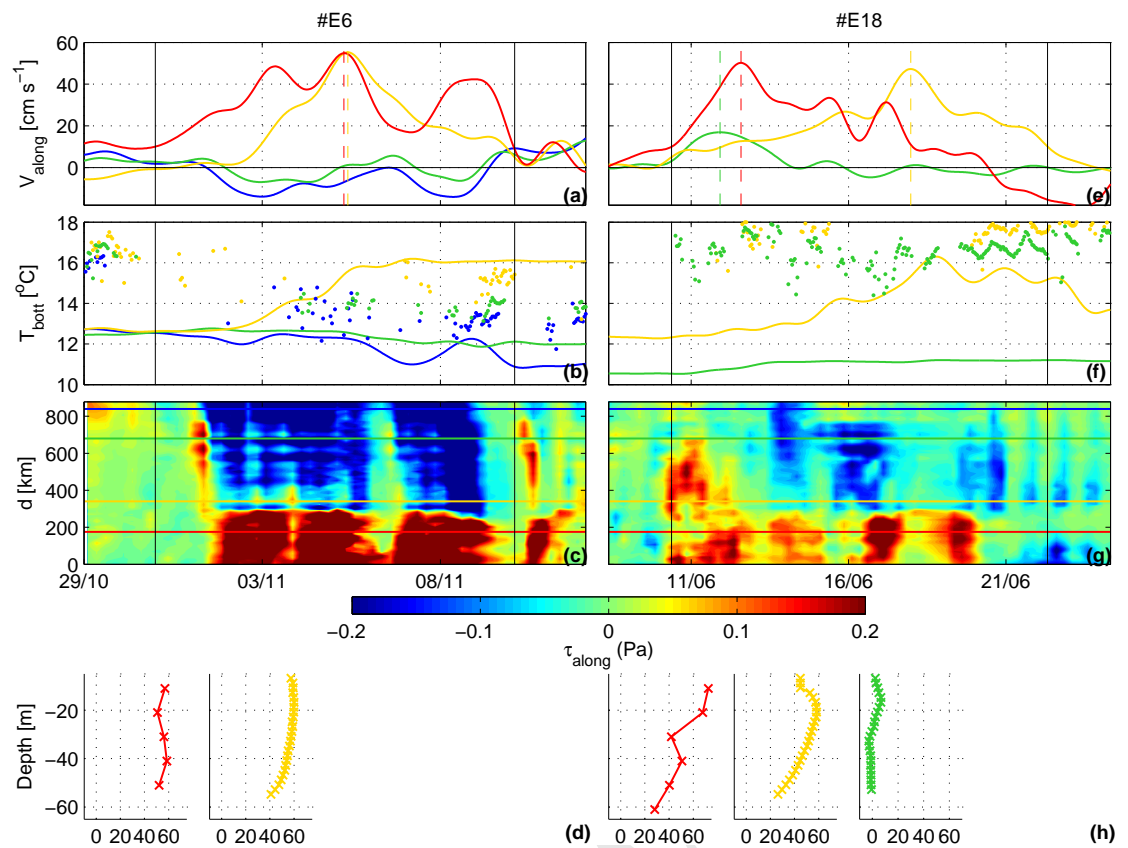

Figure 4: Strong events. Same as Figure 2 for \#E6: left column; \#E18: right column.

temperature, from $12^{\circ} \mathrm{C}$ to $16^{\circ} \mathrm{C}$, was recorded on 18 June at $M 2$ (Figure 4f f). In contrast to \#E6, in mid-June, during the decay of \#E18, the poleward currents weakened and a quick temporal restoration of cold bottom temperature was observed. During this event, a succession of short wind bursts was observed during ten days over the $100 \mathrm{~m}$ isobath (Figure $4 \mathrm{~g}$ ). A positive along-shore wind stress extended along the French coast was observed at the beginning of the event, simultaneous to the event at M3. As for the 2009-2010 period, the same characteristics are observed for the strong event of 2010 (\#E37).

\section{Discussion}

Time series of current velocity and wind intensity allow for a detailed assessment of the variability over the continental shelf over different time scales. Data from the four moorings provide a large amount of informations for the study of the large-scale and local forcings involved in the BoB shelf circulation. The 

shelf circulation. Nevertheless, the large number of events and their replication from year to year allows us to identify and separate the forcings for each type of event previously identified.

To begin this inventory, the global and regional climate during ASPEX period climatological context. The station-based index of the North Atlantic Oscillation (NAO) can also be an indicator of the climate compared to other years (Table 4).

The three summer seasons were relatively warmer and wetter than the long-term

\subsection{Inventory of associated dynamics for each type of events}

Figures 5 a,b,c illustrate a schematic of three typical events (events \#E4, \#E34 and \#E6) described in the previous section superimposed to 8-day com- 
Table 4: Monthly NAO index during the ASPEX period from "The Climate Data Guide: Hurrell NAO Index (station-based)." Retrieved in December 2014 from https://climatedataguide.ucar.edu/

\begin{tabular}{ccccccccccccc}
\hline & Jan. & Feb. & Mar. & April & May & June & July & August & Sept. & Oct. & Nov. & Dec. \\
\hline 2009 & & & & & & & $\mathbf{- 2 . 0}$ & 2.2 & 1.4 & -2.2 & 2.1 & $\mathbf{- 4 . 6}$ \\
\hline 2010 & -1.9 & -3.6 & -1.5 & -2.5 & -0.8 & -0.3 & 1.7 & -1.9 & -0.2 & -0.8 & -1.5 & $\mathbf{- 5 . 6}$ \\
\hline 2011 & -1.3 & 1.9 & 0.4 & 2.1 & 1.8 & $\mathbf{- 0 . 8}$ & 0.3 & $\mathbf{- 1 . 4}$ & & & & \\
\hline
\end{tabular}

posite images of SST. The 8-day composite images of SST were the closest in time to the events. For \#E6 (figure 5 c), due to cloud coverage, the event occurred two weeks before the composite images of SST.

- Southern events (Figure 5-a) were characterized by a typical duration of 2-9 days. During these events, strong poleward along-shore currents were identified 35 at $M 1$ and $M 2$. Equatorward or weak poleward pulses were recorded at $M 3$ and $M 4$ during this type of event. These events were associated with westerly wind in the south and variable northerly wind in the north. This type of forcing was also observed during the particular bay-scale event \#E30. The SST images showed warmer water in the BoB, with colder water along the French coast and in front of the southern Brittany peninsula.

- During bay-scale events (Figure 5-b), strong along-shore currents were predominantly poleward at $M 1, M 2$ and $M 4$. Poleward events of along-shore currents were also present at $M 3$ but with lower velocity. The widening of the shelf is expected to be associated with a decrease of the current velocity (discussed below). The SST images showed a water mass, which is warmer than the ambient waters, flowing north along the French coast. Wind direction varied quickly during this type of event with lower wind stress values along the Spanish coast. Along the French coast, these events were associated with northerly wind between $M 2$ and $M 3$ and southerly wind between $M 3$ and $M 4$. This indicates a weak driving influence of the winds on the local circulation for this type of event. This also strongly suggests that some other mechanisms are able to force 
the main part of the circulation (discussed below). As shown by [41], these other mechanisms may be the driving up to $40 \%$ of the observed circulation which could not be explained by local wind forcing.

375 - Strong events (Figure 5-c) appeared during the period of measurements. The poleward flow at $M 1$ and $M 2$ was very marked during \#E6 strong event for more than 10 days. \#E6 was apparent at $M 3$ with weak poleward currents and at $M 4$ with equatorward currents. Strong and persistent westerly wind events were present over the whole bay. The SST image showed also the propagation of a warmer water mass along the French coast. An upwelling front off the southern Brittany peninsula was also present.

The strong events occurred during autumn seasons (\#E6, \#E21 and \#E24) and during summer seasons (\#E18 and \#E37). During the autumn season, along-shore currents velocity were associated with an increase of bottom temperature of $2-3{ }^{\circ} \mathrm{C}$ (Figure $4 \mathrm{~b}$ ). A low temporal decrease of bottom temperature was observed during the season. This evolution can be associated with cooling and destratification and is characterized by a slow temporal restoration of cold bottom temperature. An hypothesis proposed by [38] is that, during these periods, the stratification breakdown gives rise to a surface and a bottom front. Then, according to the thermal wind balance, a poleward surface current is generated. During the summer season, strong poleward along-shore currents were identified at all moorings during more than ten days (Figure 4 - $\mathrm{e}$ ). For the two strong events in summer, a strong burst of northwesterly wind was observed in the BoB. 3] showed that northwesterly winds can drive, during period of high stratification, downwelling circulation along the Spanish coast. Their study concluded that this downwelling triggers the poleward currents along the French coast. The same type of event occurred during ASPEX period with the same order of current velocity and bottom temperature increase. In fact, these strong events seem associated with wind forcing only and are characterized by a quick temporal restoration of cold bottom temperature (Figure $4 \mathrm{f}$ ).

It should be noted that intense IPC was observed 63] for different events (\#E6, \#E30) which can accelerate the poleward current in the southern part of the 
BoB. In winter, the southward component of the wind stress relaxes or even changes sign, allowing the extension of this surface warm poleward current in the southern part of the BoB.

Another important forcing of the along-shore current in the upper layer is the Gironde and Loire plumes [39, 40, 16]. This low-salinity surface water body fed by winter-intensified run-off from several rivers is affected by the Coriolis effect and flows toward the pole. The cross-shelf density gradient, as a consequence of the freshwater runoff can also drive this poleward current. During these events, southwesterly winds reinforce this poleward propagation. This forcing seems more important near $M 4$, where the vertical shear is enhanced at $30-40 \mathrm{~m}$ depth (Figure 3-h).

In stratified conditions, the duration of these events for more than one week 415 is an important feature. An explanation may involve the vertical shear. Indeed, 11] showed that an equilibrium can be reached due to the effect of the shear, which induces a decrease of bottom velocity, hence of bottom stress. As bottom stress nearly vanishes, this could favor the persistence and extension of downstream poleward jets.

\subsection{Estimation of the wind stress-to-current impulse response function}

The coincidence of current events and strong wind forcing is demonstrated in the above description and Figures 2, 3, 4, suggesting wind as a significant forcing of the BoB shelf currents system. As an example, Figure 6 presents the lagged cross-correlation between the depth-averaged along-shore component of the current velocity at $M 2$ and the along-shore and cross-shore components of wind stress at all locations of the $100 \mathrm{~m}$ isobath illustrated in Figure 1. As said before, wind stress components are defined as positive poleward alongshore and positive onshore. These graphs show that the along-shore current at $M 2$ is strongly correlated with the along-shore wind stress (eastward) along the Spanish coast, and strongly correlated with onshore wind stress along the French coast. Care must however be taken not to over-interpret these graphs in terms of forcing mechanisms for the currents: it is for example well known 


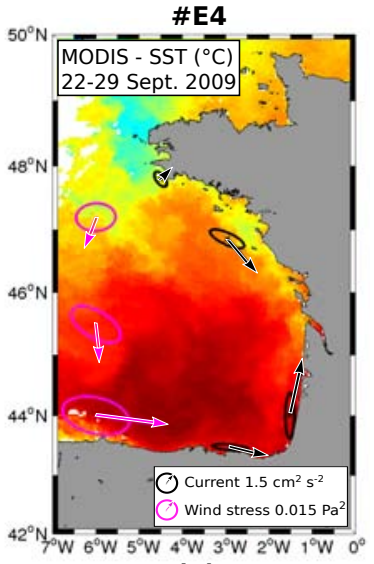

(a)

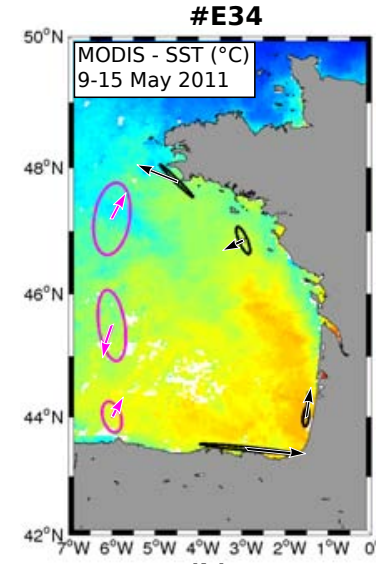

(b)

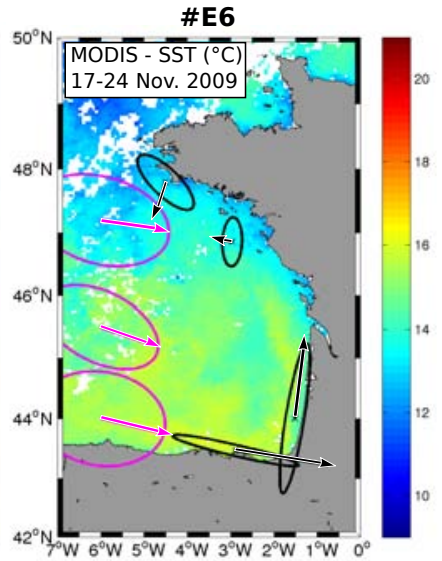

(c)

Figure 5: 8-day composite images of SST (data from MODIS) for three typical events (a: Southern event, b: Bay-scale event, c: Strong event). The arrows show the time-depthaveraged currents (black) and wind velocities (magenta) during each type of events with their associated variance ellipses. The wind velocities and variances were calculated along the 100 m isobath between $M 1$ and $M 2$ in the south, between $M 2$ and $M 3$ in the middle, and between $M 3$ and $M 4$ in the north. For clarity, they are reported along the $6^{\circ} \mathrm{W}$ meridian.

that, due to the usual wind direction during strong wind episodes in the area, along-shore wind stress (eastward) along the Spanish coast is strongly correlated with onshore wind stress on the French shelf. A causality relationship between any of these wind stress features and the current thus mechanically induces a strong correlation of the current with both wind stress signals. In much the same way, temporal correlations of the wind stress components are likely to induce correlations with the along-shore current at larger time lags than the intrinsic temporal response of the shelf currents system actually contains, and in particular for time lags for which causality can be excluded (i.e. correlation of current with wind stress at positive time lags).

The wind stress components spatial and temporal correlations, however, though non trivial, can be estimated from the wind stress data themselves. Using proper methodology, one expects that the effects discussed above could be predicted, and that a dynamical characterization of the system devoid of their influence could be designed. A first step in this direction, used to discriminate the in- 

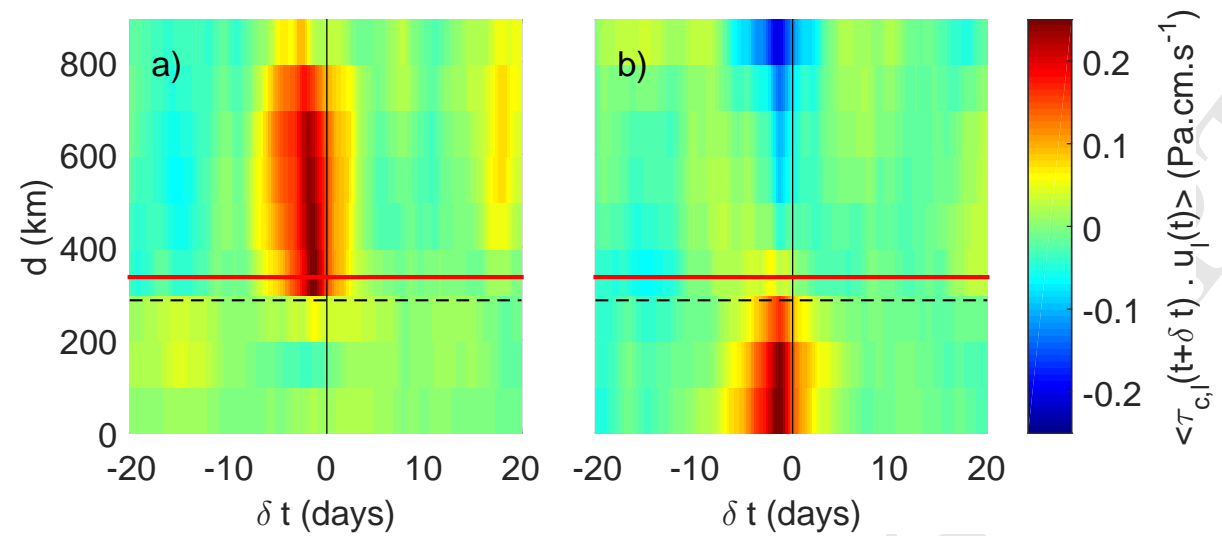

Figure 6: Lagged cross-correlations between the depth-averaged along-shore component of the current velocity at $M 2$ and the cross-shore (a) and along-shore (b) components of wind stress, along the $100 \mathrm{~m}$ isobath illustrated in Figure 1. The thick red line marks the location of the mooring. The thick dashed lines marks the approximate location of the coastline orientation change. A thin black line marks zero lag. For negative time lags, wind stress is considered at earlier instants than along-shore current.

fluences of cross- and along-shore wind stress components is described in [18], elaborating on the work of [33]. We present here a first concept to extend the approach to the study of cases in which the influence of wind at different locations and not just different instants, is to be analyzed.

In a linear setting, it seems reasonable to model the contribution of wind forcing inside the study domain to currents at mooring $m$ as:

$$
u_{m}(t)=\sum_{d=c, l} \int_{\text {coast }} d s \int_{-\infty}^{0} d \delta t K_{m}^{d}(s, \delta t) \tau^{d}(s, t+\delta t),
$$

where the $d s$ integral corresponds to summing contributions originating at all points of the $100 \mathrm{~m}$ isobath illustrated in Figure 1, the $d \delta t$ integration corresponds to summing contributions forced by wind at all locations and at all prior instants, and the summation runs on the two wind stress components. Forcing due to both along-shore $(d=l)$ and cross-shore $(d=c)$ wind stress components are considered. The two impulse response kernels $K_{m}^{c}$ and $K_{m}^{l}$ represent the intrinsic response of the currents system, and are independent of the statistical characteristics of the wind forcing. The method we have used to estimate the 
impulse response functions, which is basically a time-domain implementation of methods described in chapter 7 of [5], is described in Appendix A.

Figure 7 shows as an example the impulse response functions computed for the along-shore (Figure 7-a) and the cross-shore (Figure 7-b) components of wind stress. One can clearly observe large differences with the lagged correlations 
moorings. In summary:

- The dominance of along-shore wind stress response over cross-shore wind stress response is a generic feature observed for all locations. All locations also show a dominant influence of short time lags, of the order of 1 to 2 days.

- Along-shore currents at M4 are influenced by along-shore wind stress at all locations on the French shelf and, to a lesser extent, the Spanish shelf.

- Along-shore currents at $M 3$ are influenced by along-shore wind stress at all locations on the French shelf, but show little influence on the Spanish shelf. Two reasons can justify this observation. Firstly, 42] showed that tides are strongly amplified in the central part of the Armorican shelf. This larger tide at M3 induces larger bottom friction and thus, an offshore displacement of the along-shore current amplitude maxima [8]. This latter author has shown that the along-shore current can be trapped entirely on the slope under the effect of relative large bottom stress. This fact, joined to theoretical study of [69] which addressed the larger (smaller) velocity amplitude, in terms of shelf wave theory, due to the convergence (divergence) of depth contours, leads us to suggest that the influence of remote forcing from upstream locations on the along-shore currents have less influence at $M 3$.

- Along-shore currents at $M 1$ show a strong influence of wind at upstream locations, which rapidly reduces past the mooring location, and becomes negligible past the coastline orientation change.

- Both $M 4$ and $M 1$ show signs of influence of along-shore winds on the French shelf at longer time lags, of the order of 2 to 3 days. Though this does not seem unexpected at $M 4$, the equatorward propagation of this signal to $M 1$ can not be explained by the shelf waves discussed in Section 4.4.

\subsection{Propagation events in term of CTWs dynamics}

Figure 8 summarizes the velocity characteristics of the pulse events. Along-shore phase speed [ $\mathrm{m} \mathrm{s}^{-1}$ ] between $M 1$ and $M 2, M 2$ and $M 3$, and $M 2$ and M4 are computed using a time-lagged cross-correlation function of paired time sequences 9 , xcorr function in Matlab]. This method builds a first time- 
lag. We extended the time windows by this time-lag to be sure to catch all the event. The second time, the function estimates the time-varying correlations (with coefficient higher than 0.7) between the two signals used to compute the along-shore phase speed. Stratified and unstratified periods are distinguished (resp: Figure8 8 -a and Figure 8-b). During the stratified period, phase velocities are less than $4.3 \mathrm{~m} \mathrm{~s}^{-1}$, and can be as low as $0.4 \mathrm{~m} \mathrm{~s}^{-1}$ (event \#E18 with a maximal current speed $\sim 0.5 \mathrm{~m} \mathrm{~s}^{-1}$ ). During the unstratified period, phase speeds are much faster and can reach $12.5 \mathrm{~m} \mathrm{~s}^{-1}$.

We have seen previously than event \#E30 has different characteristics from the other bay-scale events. Here, phase velocity is larger than $80 \mathrm{~m} \mathrm{~s}^{-1}$ with a maximal current speed $\sim 0.2 \mathrm{~m} \mathrm{~s}^{-1}$ ). This event is an outlier and will not be considered.
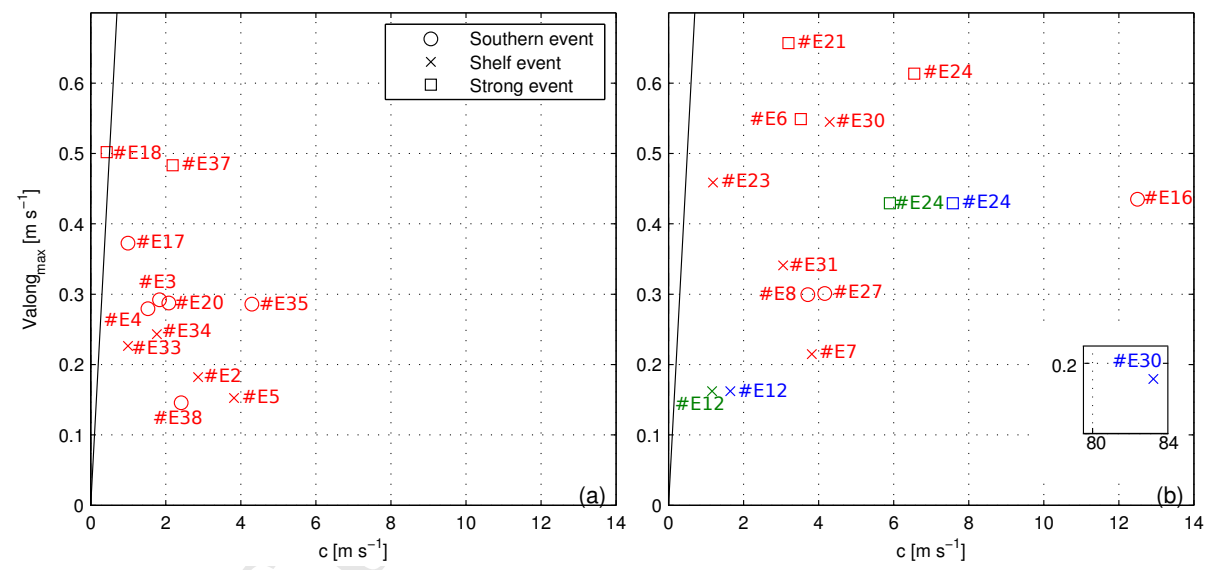

Figure 8: Maxima of vertically integrated along-shore current speed $\left[\mathrm{m} \mathrm{s}^{-1}\right]$ as a function of along-shore phase speed [ $\mathrm{m} \mathrm{s}^{-1}$ ] of these maxima, between $M 1$ and $M 2$ (in red), $M 2$ and $M 3$ (in green) and $M 2$ and $M 4$ (in blue) during stratified (a) and unstratified (b) periods. For completeness, we add a zoom for an extreme event (b). The black line represents the linear function $c=$ Valong $\max$.

Like [3], we seek explanation of these propagation features in term of CTWs. Properties of CTWs were computed for typical BoB cross shelf and slope topographies and stratifications, using the Matlab codes of [8]. The first mode phase speeds range from 3-4 $\mathrm{m} \mathrm{s}^{-1}$ (offshore northern Spanish coast) to 9- 
$10 \mathrm{~m} \mathrm{~s}^{-1}$ (offshore French coast at its widest). This first mode may thus ex-

${ }_{525}$ plain the fastest events propagations during both stratified and unstratified conditions. As for slowest phase propagations (less than 2-3 $\mathrm{m} \mathrm{s}^{-1}$ ), they may be explained by shelf restricted modes, which range from $0.7 \mathrm{~m} \mathrm{~s}^{-1}$ (northern Spanish shelf) to $\sim 2.5 \mathrm{~m} \mathrm{~s}^{-1}$ (French shelf at its widest) for the first mode phase speed (restricted to the shelf). It is particularly interesting to note that the computed along-shore velocity (not shown) is almost barotropic, whether in stratified or unstratified periods. This is in line with the weak value of the shelf Burger number $S=N H / f L(N$ : Brunt-Väisälä frequency, $H$ : shelf depth, $f$ : Coriolis frequency, $L:$ shelf width), which ranges from $\sim 0.01-0.1$ (winter) to 0.03-0.2 (summer). [13], through scale analysis, show that the response of a wide 535 shelf to synoptic wind fluctuations is barotropic with $S^{2}<<1$ and restricted to the shelf with more restrictive condition $(S<<1)$.

The estimations obtained for CTW in the area using the cited methodology are valid for simple straight coasts and horizontally constant stratification profiles: the particularly contorted topography of the BoB, the presence of the IPC and non-linear effects are certainly affecting these simple results, notably through dispersion effects. For instance, for event \#E24, the along-shore currents show poleward propagating signals with phase speeds of $6.5 \mathrm{~m} \mathrm{~s}^{-1}$ between $M 1$ and $M 2,5.9 \mathrm{~m} \mathrm{~s}^{-1}$ between $M 2$ and $M 3$ and $7.6 \mathrm{~m} \mathrm{~s}^{-1}$ up to the Penmarc'h section (Figure 8-b).

${ }_{545}$ It has been shown that the presence of persistent currents (as the IPC) can strongly modify the CTWs by increasing the wave frequency as the current propagates in the same direction as CTWs. In addition, if the mean current is sheared, the wave structure and dispersion characteristic will be strongly modified in the unstratified limit of barotropic shelf waves [49]. The decreasing speed of the propagating signals may also result from scattering of CTWs into higher modes due to curvature of shoreline and bathymetry [71, 72]. Moreover, the scattering process may be strongly modified in the presence of a mean current. In particular, a sheared mean current flowing in the same direction as the free phase speed may severely limit the number of forward propagating modes and 

cation increases the free-wave phase speeds and may eliminate the backward propagating modes [72]. [75] extended these ideas to fully nonlinear dynamics where mesoscale flows have been linked to adjustment of current over topographic features. As also shown by [58], the topographic variations of the coastline can transform CTWs into non-linear waves or an eddy train. These non-linear effects may also be significant in this study for high current and low phase propagation speeds (e.g. \#E18), with Froude numbers $(F r=V a l o n g / c$, Valong: along-shore current speed, $c$ : along-shore phase speed) close to unity.

\section{Conclusion}

The low-passed along-shore currents, observed from four locations throughout the water column, were used to describe the circulation of the shelf over the Bay of Biscay and its temporal evolution. The nearly two-year time series provided a large amount of data over a large domain for the study of the largescale and local forcings involved in this circulation. As a first approach, the large number of events and their repeated occurrence from year to year allowed us to separate events into distinct types. This required a description and a characterization over time of the events. Based on this inventory, we showed that three kinds of events occurred, which we defined as southern events, bay-scale events and strong events. In all cases, the low-passed along-shore currents revealed strong coastal poleward currents. The simultaneous influence of different forcing scales adds complexity to distinguish the ones generating or influencing the shelf circulation.

We showed however that the dynamics at the moorings in the south is clearly controlled by the along-shore wind stress along the Spanish coast at short time lags, of the order of 1 to 2 days. Further north, along-shore currents at M3 and $M 4$ are influenced by along-shore wind stress at all locations on the French shelf with the same time lag.

Taken together, these elements shed some light on the contrasting characteristics 
of southern events and bay-scale events. Currents at $M 3$ and $M 4$ are influenced trast, currents at $M 1$ and $M 2$ are only forced by wind stress along the Spanish coast. In the case of southern events, westerly winds blow in the south of the $\mathrm{BoB}$, the response at $M 1$ and $M 2$ is strong, while variable northerly or northwesterly winds blow in the north, the response to local forcing at M3 and M4 counteracts the remotely induced response, leading to a weak total response. In the case of bay-scale events, southwesterly winds blow along the French coast, with a weak wind along the Spanish one. The response at $M 4$ and $M 3$ is thus dominant, and the response at $M 1$ and $M 2$ is highly variable. The case of strong events seems qualitatively different, in the sense that these events are associated to high values of the Froude number, thus likely to be significantly influenced by non-linear effects. The bottom temperature signature at $M 2$ moreover hints to a possible role of the density anomaly of the advected water mass in its selfpropagation.

The analysis further demonstrated some influence of along-shore winds at longer time lags, of the order of 2 to 3 days. The propagation velocities observed lend consistency to the hypothesis of remote forcing through CTW propagation. Indeed, the fastest events propagations could be explained by the first mode of CTWs, while the slower phase propagation could be explained by barotropic shelf restricted modes. These propagating signals could be also affected by scattering of CTWs .

The duration of the events, more than 10 days in stratified conditions, could be linked to the decrease of bottom stress due to the decreases of horizontal velocity with depth. The poleward pulses were also strongly affected by the extension of the IPC in the BoB. Finally, autumn seasons are marked by the breakdown of stratification, which had been shown in a previous study and the present work to be a triggering mechanism of strong poleward currents. Although previous experiments have described poleward currents over the shelf of the BoB, many questions still remain on the components of these currents variability at meso- and subinertial scales and their generation mechanisms. This 
analysis will be the main goal of forthcoming numerical experiments. Planned model runs will help us to estimate how these currents propagate and to study the possible connections between the ASPEX moorings, including the ones on the outer-shelf and the upper-slope. It is even more important to investigate these coastal currents in light of their strong impact on the ecosystem as the transport of toxic water masses, larvae, biogenic particles, and pollutants in the along-shore direction or the retention of them in the cross-shore direction.

\section{Acknowledgments}

The ASPEX project was part of the EPIGRAM project supported by the Agence Nationale de la Recherche [French National Research Agency] (Grant ANR-08-BLAN-0330-01) and CNRS/INSU national programme LEFE/IDAO. This work is part of the research program PROTEVS funded by DGA and conducted by SHOM, the French Navy Hydrographic and Oceanographic Institute. Marion Kersalé acknowledges support from the SHOM via a postdoctoral fellowship. Special thanks go to the institutes that provided the data for this study: IFREMER and Météo-France. Users can access the data, available at the LPO Laboratory, from the PI of the ASPEX Project, L. Marié (Louis.Marie@ifremer.fr). The authors would also like to thank the captains and crews of R/Vs Côtes de la Manche, Thalassa and Suroît. We are warmly grateful to the technical staff who worked on the preparation, deployment and the recovery of the instruments. The authors thank Julien Mader and MarieNoelle Bouin for precious help, comments and useful discussions. We thank the Basque Energy Agency for the data from the Metocean buoy of the Biscay Marine Energy Platform (BIMEP), which gave us access to an unique database for analyze and understand our results. We also thank Patrice Bellec for help in processing climatological hydrographic databases. Finally, we thank the two reviewers of this manuscript for their constructive comments. 


\title{
Appendix A. Inventory of all events
}

\author{
Appendix A.1. 2009-2010 period
}

Figure A1-a shows the intensity of the depth-averaged along-shore currents from 15 July 2009 to 30 June 2010. Eighteen events of poleward currents were identified during this period. The specific characteristics of the different events are described in Table 2 .

Ten events are classified as bay-scale events. Four events (\#E7, \#E9, \#E11 and \#E12) were generated during episodes of intense Iberian Poleward Current (IPC), listed by [63]. It must also be emphasized that storm Xynthia occurred during event \#E14 [44]. During bay-scale events, the wind was highly variable in the bay (Figure A1 b). Generally, the events were associated with a succession of short bursts of wind with positive wind stress values along the French coast. During six events, with a typical duration of 2-8 days, along-shore currents were more intense on the north Spanish shelf and on the Aquitaine shelf. These southern events were associated with strong values of along-shore components of the wind stress (up to 0.2 Pa, Figure A1-b). Positive wind stress values are recorded along the Spanish coast (first $300 \mathrm{~km}$ along the $100 \mathrm{~m}$ isobath) and negative wind stress values along the French coast.

660 Two strong events (\#E6 and \#E18) were identified during November 2009 and June 2010 (Figure A1-a). Strong positive wind stress values were identified along the Spanish coast and strong negative wind stress values along the French coast (Figure A1 b). Succession of intense short bursts or extended wind was observed during these events.

The first part of record (from July to October) was characterized by the presence of a thermal stratification and by currents typically more intense in the first $45 \mathrm{~m}$ of the water column (Figure $\mathrm{A2}$ ). During this period, equatorward currents at $M 3$ (Figure A2-c) were detected in the first $40 \mathrm{~m}$ of the water column. This depth corresponded to the depth of the seasonal thermocline, which was estimated with ScanFish sections in mid-July 2009 (data not shown). During event \#E6, an increase of along-shore currents velocity, over the first $60 \mathrm{~m}$ 
of the water column with a slight decrease of the intensity near the bottom, was associated with an increase of bottom temperature of $2-3^{\circ} \mathrm{C}$ at $M 2$, which marked the end of the vertical stratification (Figure A2 f). After that, a slow decrease of bottom temperature was observed between October to April. This period was characterized by currents relatively uniform vertically for $M 1, M 2$ and $M 3$ (Figures A2-c,e,g). 21 January was marked by a thermal inversion in the northern part of the $\mathrm{BoB}$ (Figure $\mathrm{A} 2 \mathrm{-b}$ ). The pulses at $M 4$, occurring after this inversion, showed intense currents down to $30 \mathrm{~m}$ depth (Figure A2 -a). The water column was relatively well mixed until event \#E17, when the establishment of a thermal stratification was observed in mid-May (increase of surface temperature from 14 to $18^{\circ} \mathrm{C}$ ). The mean bottom temperature increased linearly from $12^{\circ} \mathrm{C}$ to $13^{\circ} \mathrm{C}$. In contrast, event \#E18 was associated with an increase of the bottom temperature up to $4^{\circ} \mathrm{C}$ at $M 2$, while surface temperature remained constant at $18^{\circ} \mathrm{C}$ (Figure $\mathrm{A2}$-f). In mid-June, during the decay of event \#E18, the poleward currents weakened and a quick temporal restoration of cold bottom temperature was observed. 

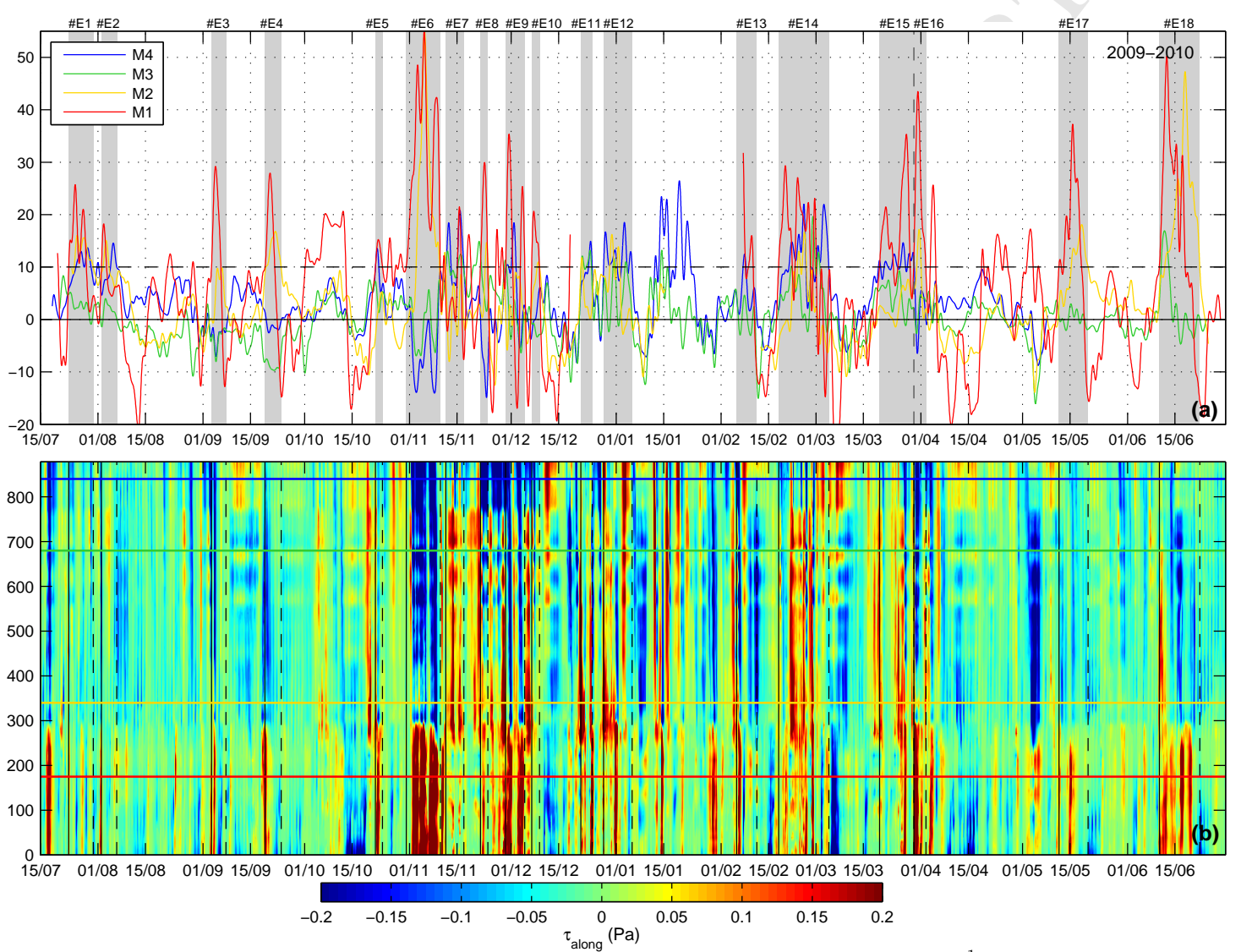

Figure A1: (a) Temporal evolution of the depth-averaged along-shore component of the current velocity [ $\mathrm{cm} \mathrm{s}^{-1}$ ] at M1, M2, M3 and M4 for the $2009 / 2010$ period. The shaded areas show the poleward events recorded. (b) Temporal evolution with distance $[\mathrm{km}]$ along the $100 \mathrm{~m}$ isobath of the along-shore component of the wind stress $[\mathrm{Pa}]$ from the AROME model. The horizontal lines represent the distances where the moorings are positioned. The vertical solid (dotted) lines represent the beginning (end) of the poleward events recorded. 

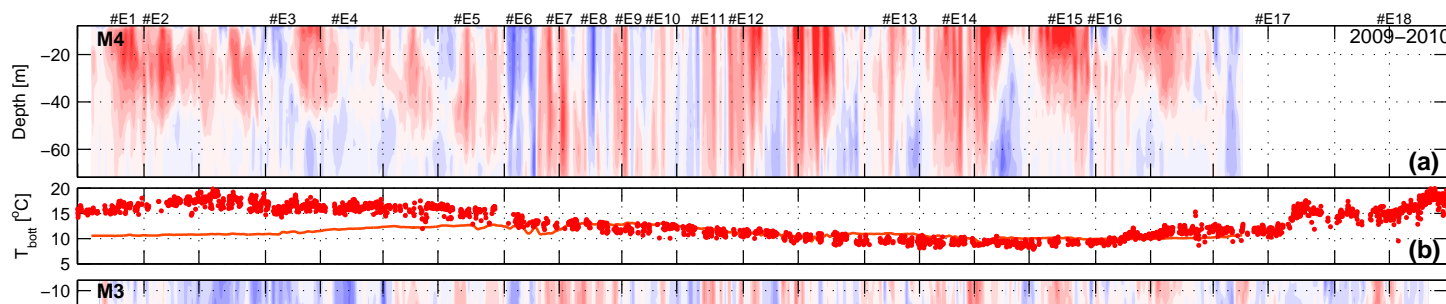

$-20-1 . . . .11$.

言 -30

言 $-40-$

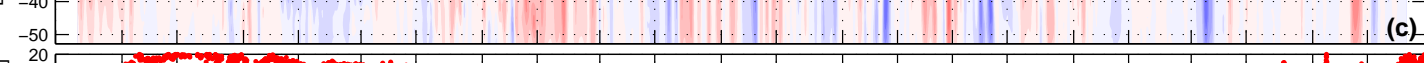

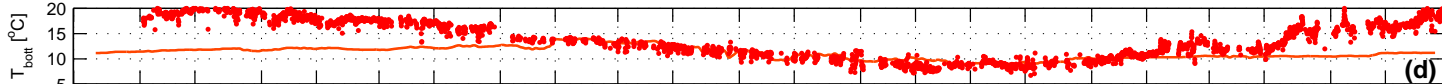
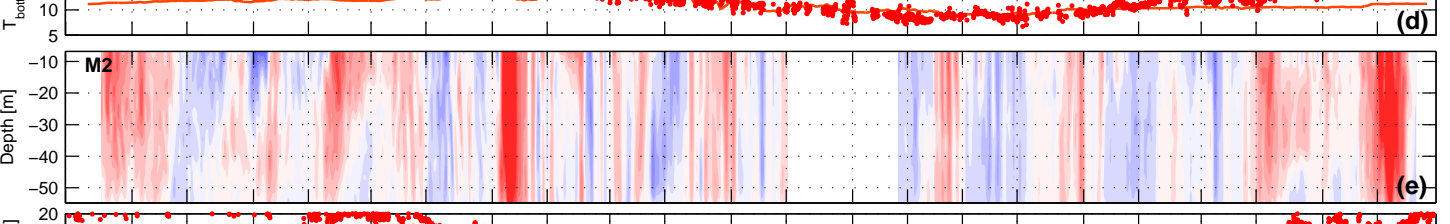

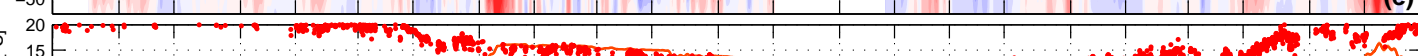

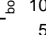

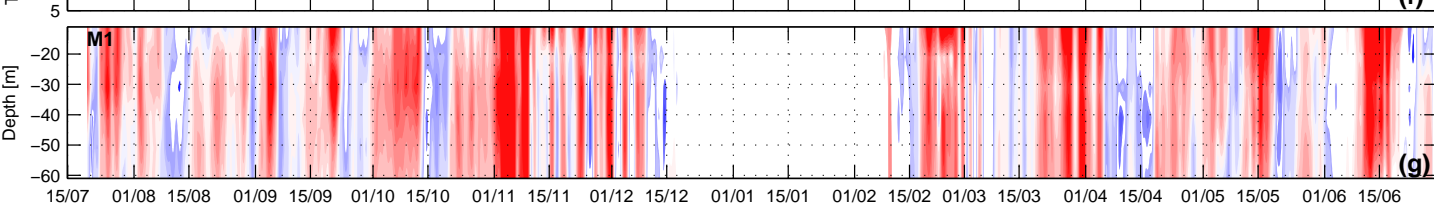

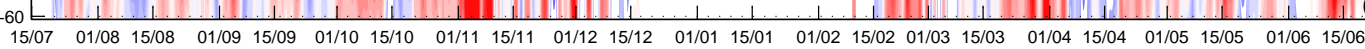

$\begin{array}{lllllll}-30 & -20 & -10 & 0 & 10 & 20 & 30\end{array}$

Figure A2: Temporal evolution with depth of the along-shore component of the current velocity [cm s $\left.{ }^{-1}\right]$ at M4 (a), M3 (c), M2 (e) and M1 (g) for the 2009/2010 period. The red lines represent the temporal evolution of the bottom temperature $\left[{ }^{\circ} \mathrm{C}\right]$ recorded at ASPEX moorings (b: M4, d: M3, f: M2). Red dots represent the surface temperature $\left[{ }^{\circ} \mathrm{C}\right]$ from SEVIRI images. 


\section{Appendix A.2. 2010-2011 period}

Twenty events of poleward currents were identified from 1 September 2010 to 7 August 2011 (Figure A3-a). The specific characteristics of the different events are described in Table 3 . Seven events could be classified as southern events (Figure A3-a). The wind stress along the coast is similar to that of southern events of 2009-2010 (Figure A3-b). The events were associated with high positive values of along-shore components of the wind stress along the Spanish coast and average negative value along the French coast.

Ten events were identified as bay-scale events. Generally, the observed wind stress values are dominated by along-shore with a succession of several wind bursts along the French coast (Figure A3-b). For events \#E23, \#E25, \#E29, \#E32 and \#E33, strong positive values of along-shore components of the wind stress were also observed along the Spanish coast. For events \#E30 and \#E31, the wind stress along the coast is more similar to that of southern events with positive wind stress over the Spanish shelf and negative values over the French shelf.

${ }_{05}$ As for the period 2009-2010, we can distinguish three strong events, with a duration between 3-15 days. Two events in October-November 2010 (events \#E21 and \#E24) and one at the end of July 2011 (event \#E37). Succession of intense short bursts or extended wind was also observed during these events. During event \#E21, positive wind stress values were recorded along the Spanish coast while more variable wind was present along the French coast.

The first part of this time series (from September to October) was characterized by the presence of a thermal stratification and by currents typically more intense in the first $45 \mathrm{~m}$ of the water column (Figures A4-a,e,g). During events \#E21, \#E22, \#E23 and \#E24, along-shore currents were associated with an increase of bottom temperature of $2-3^{\circ} \mathrm{C}$ (Figures A4-b,d,f). Event \#E24 marked the end of the vertical stratification (Figure A2 f). A slow temporal decrease of bottom temperature was observed after this event, as in 2009-2010. This period was characterized by currents relatively uniform vertically (Figures A2 a,c,e,g). 
January 7 was marked by a thermal inversion in the northern part of the BoB

${ }_{720}$ (Figure A4 b). After this inversion, the events were reduced to the top $40 \mathrm{~m}$ of the water column at $M 4$. The water column was relatively well mixed until mid-April. The establishment of a thermal stratification was observed by the increase of surface temperature from 12 to $18^{\circ} \mathrm{C}$ and a bottom temperature around $12{ }^{\circ} \mathrm{C}$ from mid-April to June. The establishment of a thermal stratification occurred earlier than in 2010. With the thermal stratification, the core of the events encompassed only the first $10-40 \mathrm{~m}$ of the water column at $M 4$ (Figures A4-a). Associated with the sharply rising along-shore current velocity of event \#E37, an increase in bottom temperature from $13^{\circ} \mathrm{C}$ to $18^{\circ} \mathrm{C}$ was recorded on 18 July at M2 (Figure A4f). As for the strong event of 2010 (event 730 \#E18), a strong increase of bottom temperature (up to $4^{\circ} \mathrm{C}$ ) was recorded. 

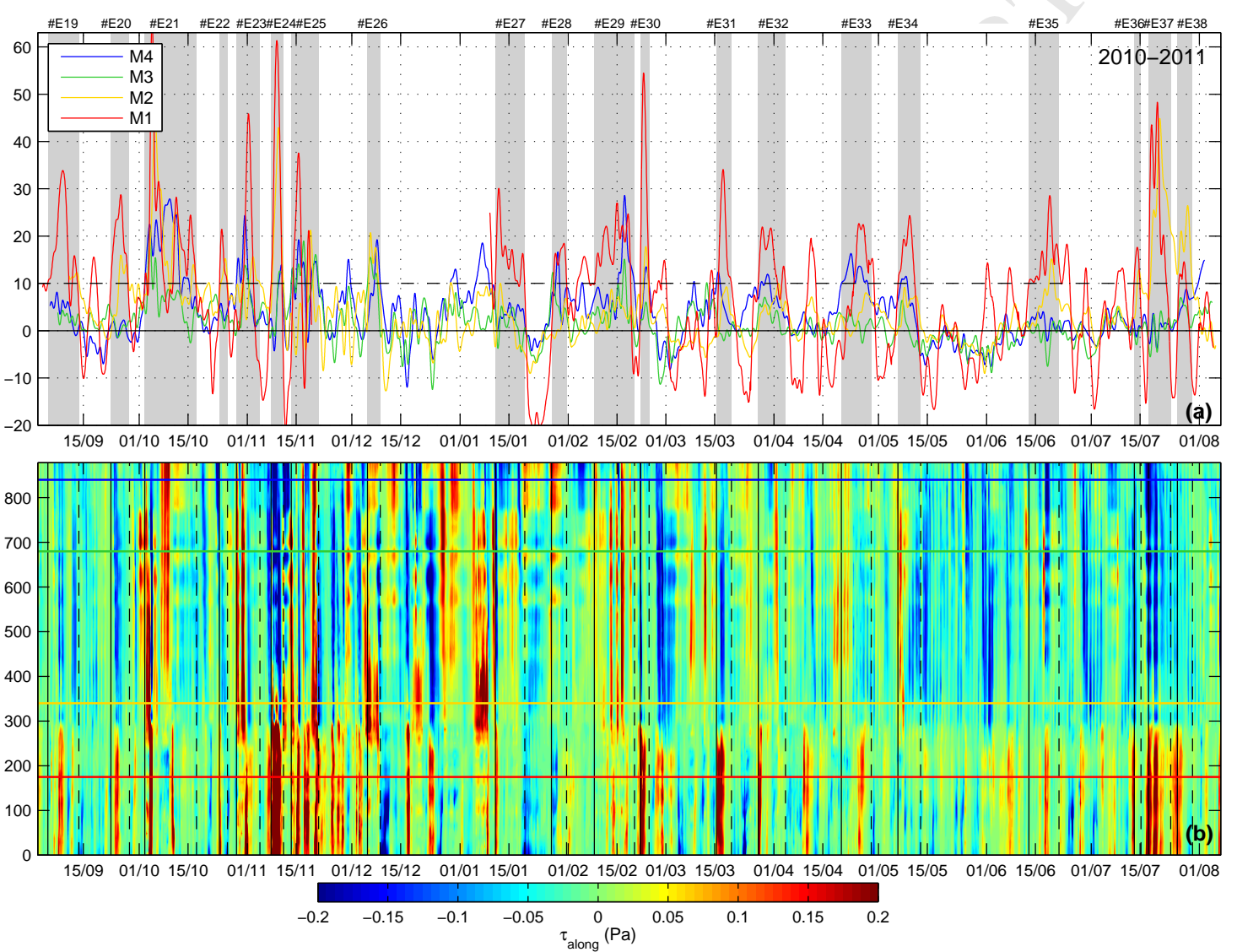

Figure A3: Same as Figure A1 for the 2010/2011 period. 


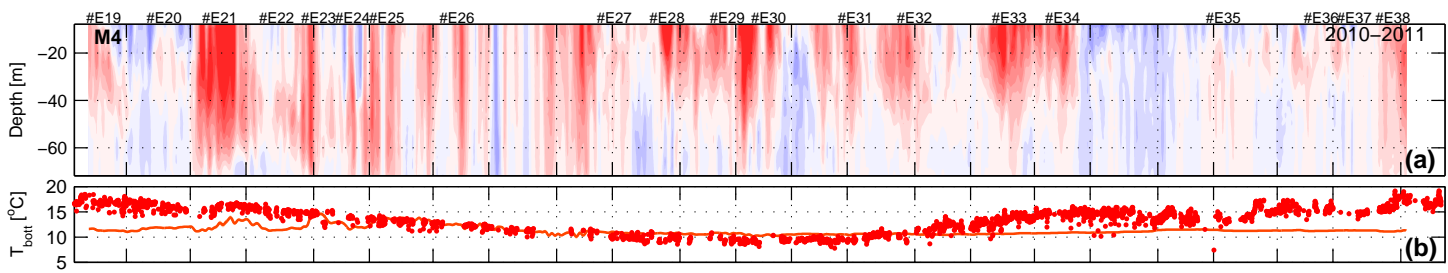

$\vdash$

E $-20-$

言 $-30-$

容 -40

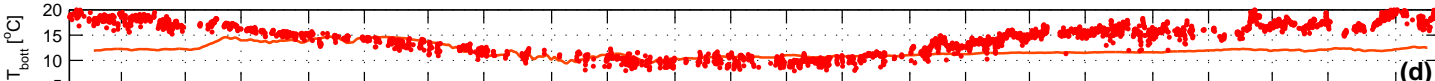

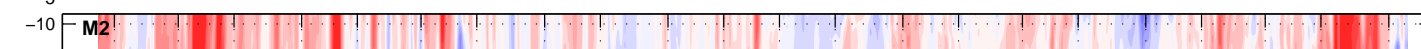

E -20

言 $-30-$

-50

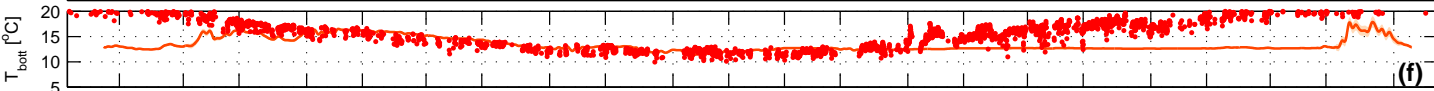

$r^{-2}$

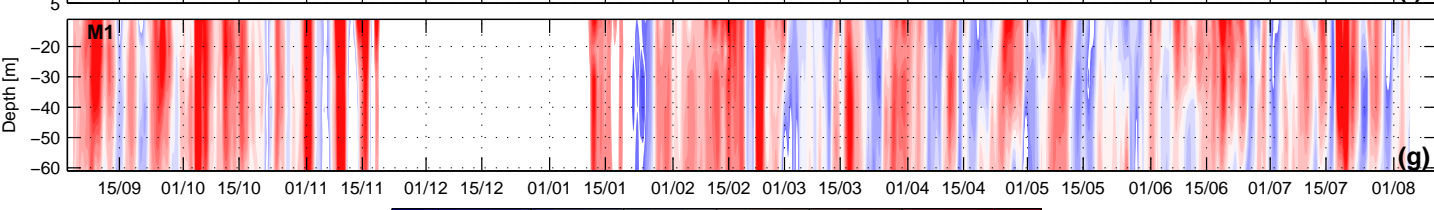

$\begin{array}{lllllll}-30 & -20 & -10 & 0 & 10 & 20 & 30\end{array}$

Figure A4: Same as Figure A2 for the 2010/2011 period. 


\section{Appendix B. Wind stress-to-current impulse response function esti- mation}

In order to estimate the two impulse response functions, we have chosen to use a least-squares criterion, i.e. we use as defining criterion for $K_{m}^{l, c}$ that they

735

$$
E\left(K_{m}^{l, c}\right)=\int_{t}\left[u_{m}(t)-\sum_{d=c, l} \int_{\text {coast }} d s \int_{-\infty}^{0} d \delta t K_{m}^{d}(s, \delta t) \tau^{d}(s, t+\delta t)\right]^{2} d t
$$

This error function does not involve time or space derivatives of the kernels. Differentiating straightforwardly $E\left(K_{m}^{l, c}\right)$ with respect to the values of the kernels at all locations and all instants, and requesting all derivatives to be zero yields the following integral equations for $K_{m}^{l, c}$ :

$$
\begin{aligned}
& \int_{t} \tau^{c}(s, t+\delta t) \sum_{d=c, l} \int_{s^{\prime}, \delta t^{\prime}} K_{m}^{d}\left(s^{\prime}, \delta t^{\prime}\right) \tau^{d}\left(s^{\prime}, t+\delta t^{\prime}\right) d s^{\prime} d \delta t^{\prime} d t=\int_{t} \tau^{c}(s, t+\delta t) u_{m}(t) d t \\
& \int_{t} \tau^{l}(s, t+\delta t) \sum_{d=c, l} \int_{s^{\prime}, \delta t^{\prime}} K_{m}^{d}\left(s^{\prime}, \delta t^{\prime}\right) \tau^{d}\left(s^{\prime}, t+\delta t^{\prime}\right) d s^{\prime} d \delta t^{\prime} d t=\int_{t} \tau^{l}(s, t+\delta t) u_{m}(t) d t
\end{aligned}
$$

740

One recognizes in these equations the lagged cross-correlations between the wind stress components, and their cross-correlations with the current at the mooring location.

Introducing the notations:

$$
\begin{aligned}
& C^{d d^{\prime}}\left(s, s^{\prime} ; \delta t-\delta t^{\prime}\right)=\int_{t} \tau^{d}(s, t+\delta t) \tau^{d^{\prime}}\left(s^{\prime}, t+\delta t^{\prime}\right) \\
& C^{d m}(s ; \delta t)=\int_{t} \tau^{d}(s, t+\delta t) u_{m}(t) d t
\end{aligned}
$$

the equations can be transformed to:

$$
\begin{aligned}
& \sum_{d=c, l} \int_{s^{\prime}, \delta t^{\prime}} C^{c d}\left(s, s^{\prime} ; \delta t-\delta t^{\prime}\right) K_{m}^{d}\left(s^{\prime}, \delta t^{\prime}\right) d s^{\prime} d \delta t^{\prime}=C^{c m}(s ; \delta t) \\
& \sum_{d=c, l} \int_{s^{\prime}, \delta t^{\prime}} C^{l d}\left(s, s^{\prime} ; \delta t-\delta t^{\prime}\right) K_{m}^{d}\left(s^{\prime}, \delta t^{\prime}\right) d s^{\prime} d \delta t^{\prime}=C^{l m}(s ; \delta t)
\end{aligned}
$$

Basically, what is required is that the modeled signal have the same lagged crosscorrelation with the wind stress components as the original one. Introducing in these equations cross-correlation functions of the form

$$
C^{d d^{\prime}}\left(s, s^{\prime}, \delta t-\delta t^{\prime}\right)=\delta_{d d^{\prime}} \delta\left(s-s^{\prime}\right) \delta\left(\delta t-\delta t^{\prime}\right)
$$


one easily sees that $K_{m}^{d}(s, \delta t)$ is actually the lagged cross-correlation one would obtained between wind stress and current, if the wind stress components were uncorrelated, and delta-correlated in time and space. Recovering the kernels can be considered a way to abstract the statistical characteristics of the input variables from their observed cross-correlation with the output variable.

These equations can be straightforwardly discretized. Solving their discrete analog, however, requires the inversion of a fairly large matrix, and tends to enhance small-scale noise from the imperfect data. We have thus practically performed this operation by projection of the right-hand-side on the eigenmodes of the matrix associated to its 100 largest eigenvalues, computed using the Arnoldi method [60]. 


\section{References}

[1] Alvarez, I., Gomez-Gesteira, M., deCastro, M., Carvalho, D., 2014. Comparison of different wind products and buoy wind data with seasonality and interannual climate variability in the southern Bay of Biscay (2000-2009). Deep-Sea Res. II 106, 38 - 48. doi $10.1016 / \mathrm{j} . \mathrm{dsr} 2.2013 .09 .028$

[2] Amol, P., Shankar, D., Aparna, S., Shenoi, S., Fernando, V., Shetye, S., Mukherjee, A., Agarvadekar, Y., Khalap, S., Satelkar, N., 2012. Observational evidence from direct current measurements for propagation of remotely forced waves on the shelf off the west coast of India. J. Geophys. Res. 117. doi $10.1029 / 2011 \mathrm{JC} 007606$.

[3] Batifoulier, F., Lazure, P., Bonneton, P., 2012. Poleward coastal jets induced by westerlies in the Bay of Biscay. J. Geophys. Res. 117. doi $10.1029 / 2011$ JC007658

[4] Beardsley, R.C., Lentz, S.J., 1987. The Coastal Ocean Dynamics Experiment collection: An introduction. J. Geophys. Res. 92, 1455-1463. doi $10.1029 / J C 092 i C 02 p 01455$.

[5] Bendat, J.S., Piersol, A.G., 2011. Random data: analysis and measurement procedures. volume 729. John Wiley \& Sons.

[6] Bender, L., DiMarco, S., 2008. Quality control and analysis of acoustic Doppler current profiler data collected on offshore platforms of the Gulf of Mexico, OCS Study MMS 2008-XXX. U.S. Dept. of the Interior, Minerals Mgmt. Service, Gulf of Mexico OCS Region, New Orleans, LA (2008) 63 pp. .

[7] Brink, K., Robinson, A., eds., 1998. The global coastal ocean: Processes and Methods. volume 10. New York, John Wiley \& Sons.

[8] Brink, K.H., 2006. Coastal-trapped waves with finite bottom friction. Dyn. Atmos. Oceans 41, 172-190. doi $10.1016 / j$.dynatmoce.2006.05.001. 
[9] Buck, J., Daniel, M., Singer, A., 2nd Ed., 2002. Computer Explorations in Signals and Systems Using MATLAB. volume 10. Prentice Hall, Upper Saddle River, N.J.

[10] Carton, J., 1984. Coastal circulation caused by an isolated storm. J. Phys. Oceanogr. 14, 114-124. doi $10.1175 / 1520-0485(1984) 014<0114:$ CCCBAI >2.0.CD;2

[11] Chapman, D.C., Lentz, S.J., 1997. Adjustment of stratified flow over a sloping bottom*. J. Phys. Oceanogr. 27, 340-356. doi $10.1175 / 1520-0485(1997) 027<0340:$ AOSFOA>2 . 0.CO;2

[12] Charria, G., Lazure, P., Le Cann, B., Serpette, A., Reverdin, G., Louazel, S., Batifoulier, F., Dumas, F., Pichon, A., Morel, Y., 2013. Surface layer circulation derived from Lagrangian drifters in the Bay of Biscay. J. Mar. Sys. 109-110, S60-S76. doi:10.1016/j.jmarsys.2011.09.015.

[13] Clarke, A.J., Brink, K., 1985. The response of stratified, frictional flow of shelf and slope waters to fluctuating large-scale, low-frequency wind forcing. J. Phys. Oceanogr. 15, 439-453. doi: $10.1175 / 1520-0485(1985) 015<0439:$ TROSFF>2 . 0.CO;2.

[14] Colas, F., 2003. Circulation et dispersion Lagrangiennes en Atlantique Nord-Est. Ph.D. thesis. Université de Bretagne Occidentale, Brest, France.

[15] Farrell, H., Gentien, P., Fernand, L., Lazure, P., Lunven, M., Youenou, A., Reguera, B., Raine, R., 2014. Vertical and horizontal controls of a haptophyte thin layer in the Bay of Biscay, France. Deep-Sea Res. II 101, 80-94. doi: $10.1016 / \mathrm{j} . \mathrm{dsr} 2.2013 .10 .008$.

[16] Ferrer, L., Fontán, A., Mader, J., Chust, G., González, M., Valencia, V., Uriarte, A., Collins, M., 2009. Low-salinity plumes in the oceanic region of the Basque Country. Cont. Shelf Res. 29, 970-984. doi:10.1016/j.csr.2008.12.014. 
[17] Flores-Vidal, X., Durazo, R., Zavala-Sansón, L., Flament, P., Chavanne,

C., Ocampo-Torres, F., Reyes-Hernández, C., 2014. Evidence of inertially generated coastal-trapped waves in the eastern tropical Pacific. J. Geophys. Res. 119, 3121-3133. doi 10.1002/2013JC009118.

[18] Fontán, A., Cornuelle, B., 2015. Anisotropic response of surface circulation to wind forcing, as inferred from high-frequency radar currents in the southeastern Bay of Biscay. J. Geophys. Res. 120, 2945-2957. doi $10.1002 / 2014 \mathrm{JC} 010671$

[19] Fontán, A., González, M., Wells, N., Collins, M., Mader, J., Ferrer, L., Esnaola, G., Uriarte, A., 2009. Tidal and wind-induced circulation within the Southeastern limit of the Bay of Biscay: Pasaia Bay, Basque Coast. Cont. Shelf Res. 29, 998-1007. doi $10.1016 /$ j.csr.2008.12.013.

[20] Freeland, H., Boland, F., Church, J., Clarke, A., Forbes, A., Huyer, A., Smith, R., Thompson, R., White, N., 1986. The Australian Coastal Experiment: A search for coastal-trapped waves. J. Phys. Oceanogr. 16, 1230-1249. doi $10.1175 / 1520-0485$ (1986)016<1230:TACEAS>2.0.C0;2

[21] Frouin, R., Fiúza, A.F., Ambar, I., Boyd, T.J., 1990. Observations of a poleward surface current off the coasts of Portugal and Spain during winter. J. Geophys. Res. 95, 679-691. doi 10.1029/JC095iC01p00679.

[22] Garcia-Soto, C., Pingree, R.D., 2012. Atlantic Multidecadal Oscillation (AMO) and sea surface temperature in the Bay of Biscay and adjacent regions. Journal of the Marine Biological Association of the United Kingdom 92, 213-234. doi $10.1017 / \mathrm{S} 0025315410002134$.

[23] Gill, A., Clarke, A., 1974. Wind-induced upwelling, coastal currents and sea-level changes. Deep Sea Research and Oceanographic Abstracts 21, 325-345. doi $10.1016 / 0011-7471(74) 90038-2$. 
shelf waves by the wind. J. Phys. Oceanogr. 4, 83-90. doi $10.1175 / 1520-0485(1974) 004<0083:$ TGOLSW>2.0.C0;2.

[25] Gonzalez-Pola, C., Ruiz-Villarreal, M., Lavin, A., Cabanas, J., AlvarezFanjul, E., 2005. A subtropical water intrusion spring-event in the shelf-slope of the south-western Bay of Biscay after strong windforcing pulses. Journal of Atmospheric \& Ocean Science 10, 343-359. doi $10.1080 / 17417530601129148$.

[26] Hanna, E., Cropper, T.E., Jones, P.D., Scaife, A.A., Allan, R., 2015. Recent seasonal asymmetric changes in the NAO (a marked summer decline and increased winter variability) and associated changes in the AO and Greenland Blocking Index. International Journal of Climatology 35, 2540-2554. doi $10.1002 /$ joc.4157.

[27] Hill, A.E., Hickey, B.M., Shillington, F.A., Strub, P.T., Brink, K.H., Barton, E.D., Thomas, A.C., 1998. Eastern ocean boundaries. The sea 11, $29-68$.

[28] Horányi, A., Ihász, I., Radnóti, G., 1996. ARPEGE/ALADIN: A numerical weather prediction model for Central-Europe with the participation of the Hungarian Meteorological Service. Idojárás 100, 277-301.

[29] Huthnance, J., 1984. Slope currents and "JEBAR". J. Phys. Oceanogr. 14, 795-810. doi $10.1175 / 1520-0485(1984) 014<0795:$ SCA $>2.0 . C 0 ; 2$.

[30] Kennedy, J., Morice, C., Parker, D., 2011. Global and regional climate in 2010. Weather 66, 188-194. doi:10.1002/wea.820.

[31] Kennedy, J., Morice, C., Parker, D., 2012. Global and regional climate in 2011. Weather 67, 212-218. doi:10.1002/wea.1945.

[32] Kennedy, J., Parker, D., 2010. Global and regional climate in 2009. Weather 65, 244-250. doi $10.1002 /$ wea.635 
[33] Kim, S.Y., Cornuelle, B.D., Terrill, E.J., 2009. Anisotropic response of surface currents to the wind in a coastal region. J. Phys. Oceanogr. 39, 1512-1533. doi $10.1175 / 2009 J P 04013.1$.

[41] Le Boyer, A., Charria, G., Le Cann, B., Lazure, P., Marié, L., 2013. Circulation on the shelf and the upper slope of the Bay of Biscay. Cont. Shelf Res. 55, 97-107. doi:10.1016/j.csr.2013.01.006 
[42] Le Cann, B., 1990. Barotropic tidal dynamics of the Bay of Biscay shelf: observations, numerical modelling and physical interpretation. Cont. Shelf Res. 10, 723-758. doi 10.1016/0278-4343(90)90008-A.

[43] Le Cann, B., Serpette, A., 2009. Intense warm and saline upper ocean inflow in the southern Bay of Biscay in autumn-winter 2006-2007. Cont. Shelf Res. 29, 1014-1025. doi $10.1016 /$ j.csr.2008.11.015.

[44] Liberato, M., Pinto, J., Trigo, R., Ludwig, P., Ordóñez, P., Yuen, D., Trigo, I., 2013. Explosive development of winter storm Xynthia over the subtropical North Atlantic Ocean. Natural Hazards and Earth System Science 13, 2239-2251. doi:10.5194/nhess-13-2239-2013.

[45] Maksimova, E.V., Clarke, A.J., 2013. Multiyear Subinertial and Seasonal Eulerian Current Observations near the Florida Big Bend Coast. J. Phys. Oceanogr. 43, 1691-1709. doi:10.1175/JPO-D-12-0135.1.

[46] Mazières, A., Gillet, H., Idier, D., Mulder, T., Garlan, T., Mallet, C., Marieu, V., Hanquiez, V., 2015. Dynamics of inner-shelf, multi-scale bedforms off the south Aquitaine coast over three decades (southeast bay of Biscay, France). Cont. Shelf Res. 92, 23 - 36. doi $10.1016 / j \cdot \operatorname{csr} .2014 .11 .002$

[47] Melton, C., Washburn, L., Gotschalk, C., 2009. Wind relaxations and poleward flow events in a coastal upwelling system on the central California coast. J. Geophys. Res. 114. doi:10.1029/2009JC005397.

[48] Morrow, R., Coleman, R., Church, J., Chelton, D., $1994 . \quad$ Surface eddy momentum flux and velocity variances in the Southern Ocean from Geosat altimetry. J. Phys. Oceanogr. 24, 2050-2071. doi $10.1175 / 1520-0485(1994) 024<2050$ : SEMFAV>2.0.CO;2.

[49] Narayanan, S., Webster, I., 1987. Coastally trapped waves in the presence of a barotropic shelf edge jet. J. Geophys. Res. 92, 9494-9502. doi:10.1029/JC092iC09p09494. 
[50] Noble, M.A., Ryan, H.F., Wiberg, P.L., 2002. The dynamics of subtidal poleward flows over a narrow continental shelf, Palos Verdes, $\{\mathrm{CA}\}$. Cont. Shelf Res. 22, 923 - 944. doi 10.1016/S0278-4343(01)00112-1.

[51] Paillet, J., 1999. Central water vortices of the eastern North Atlantic. J. Phys. Oceanogr. 29, 2487-2503. doi $10.1175 / 1520-0485$ (1999) 029<2487: CWVOTE $>2.0$. CO 2 .

[52] Pingree, R., 1993. Flow of surface waters to the west of the british isles and in the Bay of Biscay. Deep-Sea Res. II 40, 369-388. doi: $10.1016 / 0967-0645(93) 90022-F$

[53] Pingree, R., Le Cann, B., 1989. Celtic and Armorican slope and shelf residual currents. Prog. Oceanogr. 23, 303-338. doi $10.1016 / 0079-6611(89) 90003-7$.

[54] Pingree, R., Le Cann, B., 1992. Three anticyclonic Slope Water Oceanic eDDIES (SWODDIES) in the southern Bay of Biscay in 1990. Deep-Sea Res. I 39, 1147-1175. doi:10.1016/0198-0149(92) 90062-X.

[55] Pingree, R.D., Le Cann, B., 1990. Structure, strength and seasonality of the slope currents in the Bay of Biscay region. Journal of the Marine Biological Association of the United Kingdom 70, 857-885. doi $10.1017 /$ S0025315400059117.

[56] Raine, R., Berdalet, E., McManus, M., Yamazaki, H., 2014. Harmful algal blooms in stratified systems. Deep-Sea Res. II 101, 1-3. doi $10.1016 / \mathrm{j} . \mathrm{dsr} 2.2014 .01 .005$

[57] Relvas, P., Barton, E.D., Dubert, J., Oliveira, P.B., Peliz, A., Da Silva, J., Santos, A.M.P., 2007. Physical oceanography of the western Iberia ecosystem: latest views and challenges. Prog. Oceanogr. 74, 149-173. doi $10.1016 / \mathrm{j}$.pocean.2007.04.021 
[58] Rodney, J., Johnson, E., 2014. Meanders and eddies from topographic transformation of coastal-trapped waves. J. Phys. Oceanogr. 44, 11331150. doi $10.1175 /$ JPO-D-12-0224.1.

[59] Rubio, A., Fontán, A., Lazure, P., Gonzlez, M., Valencia, V., Ferrer, L., Mader, J., Hernández, C., 2013. Seasonal to tidal variability of currents and temperature in waters of the continental slope, southeastern Bay of Biscay. J. Mar. Sys. 109 - 110, Supplement, S121 - S133. doi $10.1016 / j \cdot$ jmarsys.2012.01.004. XII International Symposium on Oceanography of the Bay of Biscay.

[60] Saad, Y., 1992. Numerical methods for large eigenvalue problems. volume 158. SIAM.

[61] Seity, Y., Brousseau, P., Malardel, S., Hello, G., Bénard, P., Bouttier, F., Lac, C., Masson, V., 2011. The AROME-France convective-scale operational model. Mon. Wea. Rev. 139, 976-991. doi:10.1175/2010MWR3425.1.

[62] Solabarrieta, L., Rubio, A., Cárdenas, M., Castanedo, S., Esnaola, G., Méndez, F.J., Medina, R., Ferrer, L., 2015. Probabilistic relationships between wind and surface water circulation patterns in the SE Bay of Biscay. Ocean Dynam. XX, XX-XX. doi 10.1007/s10236-015-0871-5.

[63] Solabarrieta, L., Rubio, A., Castanedo, S., Medina, R., Charria, G., Hernández, C., 2014. Surface water circulation patterns in the southeastern Bay of Biscay: New evidences from HF radar data. Cont. Shelf Res. 74, 60-76. doi $10.1016 / \mathrm{j} . \mathrm{csr} .2013 .11 .022$.

[64] Thompson, R.O., 1983. Low-pass filters to suppress inertial and tidal frequencies. J. Phys. Oceanogr. 13, 1077-1083. doi $10.1175 / 1520-0485(1983) 013<1077$ :LPFTSI $>2.0$. CO 2 .

[65] Torres, R., Barton, E.D., 2006. Onset and development of the Iberian poleward flow along the Galician coast. Cont. Shelf Res. 26, 1134-1153. doi $10.1016 / j \cdot \operatorname{csr} .2006 .03 .009$. 
[66] Van Aken, H.M., 2002. Surface currents in the Bay of Biscay as observed with drifters between 1995 and 1999. Deep-Sea Res. I 49, 1071-1086. doi:10.1016/S0967-0637(02)00017-1.

[67] de la Villéon, L.P., Coatanoan, C., Edwards, M., Karstensen, J., Cardin,

V., 2005. In-situ real-time data quality control. Marine EnviRonment and Security for the European Area-Integrated Project, document id. WP03IFR-UMAN-001-01A .

[68] Vincent, A., Kurc, G., 1969. Hydrologie, variations saisonnières de la situation thérmique du Golfe de Gascogne en 1967. Rev. Trav. Inst. Pêches marit. 33, 79-96.

[69] Wang, D.P., 1980. Diffraction of continental shelf waves by irregular alongshore geometry. J. Phys. Oceanogr. 10, 1187-1199. doi $10.1175 / 1520-0485(1980) 010<1187$ : DOCSWB $>2.0$. CO 2 .

[70] Washburn, L., Fewings, M.R., Melton, C., Gotschalk, C., 2011. The propagating response of coastal circulation due to wind relaxations along the central California coast. J. Geophys. Res. 116. doi:10.1029/2011JC007502.

[71] Wilkin, J.L., Chapman, D.C., 1987. Scattering of continental shelf waves at a discontinuity in shelf width. J. Phys. Oceanogr. 17, 713-724. doi $10.1175 / 1520-0485(1987) 017<0713$ : SOCSWA $>2.0$. CO 2 .

[72] Wilkin, J.L., Chapman, D.C., 1990. Scattering of Coastal-Trapped Waves by Irregularities in Coastline and Topography. J. Phys. Oceanogr. 20, 396421. doi $10.1175 / 1520-0485(1990) 020<0396$ : SOCTWB $>2.0$. CO $; 2$.

[73] Yankovsky, A.E., Chapman, D.C., 1995. Generation of mesoscale flows over the shelf and slope by shelf wave scattering in the presence of a stable, sheared mean current. J. Geophys. Res. 100, 6725-6742. doi $10.1029 / 94 J C 03339$ 
[74] Yankovsky, A.E., Chapman, D.C., 1996. Scattering of shelf waves by a spatially varying mean current. J. Geophys. Res. 101, 3479-3487. doi $10.1029 / 95 \mathrm{JC} 02991$.

[75] Yankovsky, A.E., Chapman, D.C., 1997. Anticyclonic eddies trapped on the continental shelf by topographic irregularities. J. Geophys. Res. 102, 5625-5639. doi:10.1029/96JC03452. 